
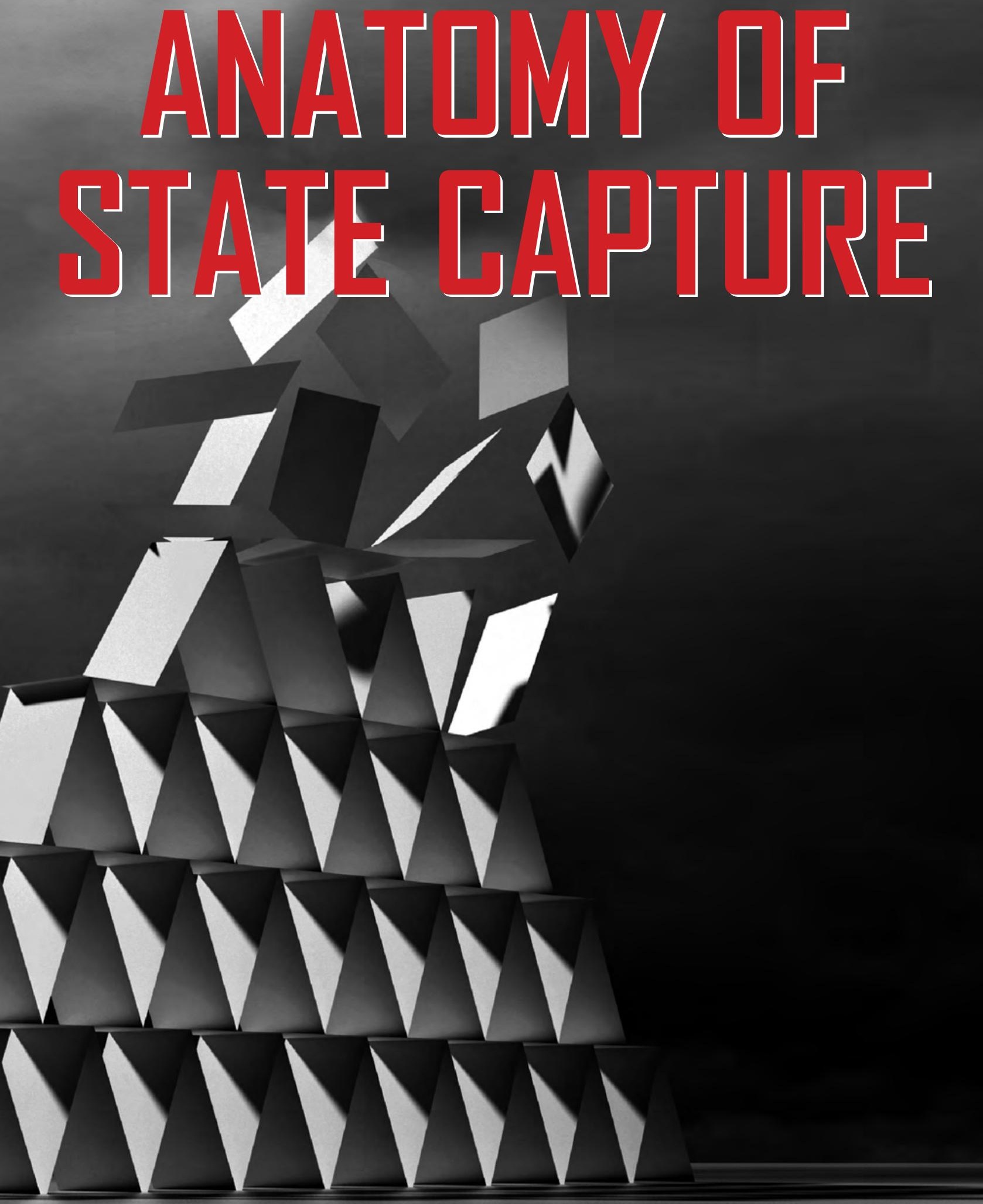

Nina Callaghan, Rabyn Foley and Mark Swilling (EDITuRS) 


\section{STATE CAPTURE AND THE ECONOMICS OF CORRUPTION: THE CASE OF TRANSNET}

Development Policy Research Unit
University of Cape Town

The financial epicentre of state capture in South Africa has been located, without any doubt, within the country's State-Owned Enterprises (SOEs). As we will elucidate below, many of these SOEs have large procurement budgets, which served as the channel through which billions of rands were illicitly transferred to individuals and private companies who formed the core recipients of the state capture project. In this chapter, we present a case study of Transnet - the country's transport SOE - which has been deeply implicated in state capture, with devastating financial results. By focusing on a single entity over several years, we are able to combine various sources of data to analyse the value, evolution and impact of illicit flows. We establish the scale of the rents available, piece together a network of the firms and individuals linked to state capture at the parastatal, produce estimates of the total value of tainted deals and kickbacks, and track one of the largest deals to show how money was paid to third-party firms and laundered internationally. Together, by focusing on Transnet, we provide a replicable empirical case study of state capture in its operational detail at one of the major nodes of organised corruption in South Africa's recent history.

For much of the 20th century, parastatals have been central to South Africa's growth trajectory, accounting for a large share of government expenditure and operating in key sectors of the economy (Freund, 2018). This remains the case today, where SOEs control significant state funds that are concentrated primarily in energy, transport, and telecommunications. In 2017, South African SOEs together earned an aggregate revenue that accounted for approximately 12\% of annual GDP (National Treasury, 2018). However, there are a small group of parastatals that make up an outsized proportion of this contribution to national revenue, and many of these are also the biggest spenders. Taking the 11 largest SOEs in South Africa, we estimate that their combined annual revenues amount to over R380bn, with capital expenditure of almost R116bn. To put this into perspective, R380bn of income is equivalent to $28 \%$ of total government revenue, and R116bn in spending is $7.5 \%$ of total annual government 
expenditure. Table 7.1 reports these figures and lists each parastatal to show both capital expenditure and revenue as a percentage of total government spending and income. ${ }^{1}$

\subsection{TRANSNET AS A KEY PLAYER}

From Table 7.1 below, it is immediately clear that the majority of revenue and investment spending resides with the country's electricity utility. Eskom reports capital expenditure of R66.5bn - making up over half of the total capital expenditure of SOEs listed here - and annual revenue of R177bn. Transnet has the second highest capex and revenue, at R21bn and R65bn, respectively. Taken together, Eskom and Transnet account for around $75 \%$ of total SOE capex in the table, and close to $6 \%$ of total government expenditure.

TABLE 7.1 Capital Expenditure and Revenue, selected SOEs: Rm, 2016/17

\begin{tabular}{|l|r|r|r|r|r|r|}
\hline SOE & $\begin{array}{c}\text { SOE } \\
\text { Capex }\end{array}$ & $\begin{array}{c}\% \text { SOE } \\
\text { Capex }\end{array}$ & $\begin{array}{c}\text { \% Total Govt. } \\
\text { Exp. }\end{array}$ & $\begin{array}{c}\text { SOE } \\
\text { Revenue }\end{array}$ & $\begin{array}{c}\% \text { SOE } \\
\text { Revenue }\end{array}$ & $\begin{array}{c}\% \text { Total Govt. } \\
\text { Revenue }\end{array}$ \\
\hline ACSA & 893 & 0,77 & 0,06 & 8583 & 2,25 & 0,63 \\
\hline City Power & 1800 & 1,55 & 0,12 & 15727 & 4,13 & 1,16 \\
\hline CSIR & 144 & 0,12 & 0,01 & 2712 & 0,71 & 0,20 \\
\hline Denel & 66 & 0,06 & 0,00 & 8057 & 2,12 & 0,60 \\
\hline Eskom & 66578 & 57,51 & 4,31 & 177136 & 46,51 & 13,09 \\
\hline PetroSA & 779 & 0,67 & 0,05 & 10357 & 2,72 & 0,77 \\
\hline SAA* & 14863 & 12,84 & 0,96 & 30385 & 7,98 & 2,24 \\
\hline SAPO & 54 & 0,05 & 0,00 & 4539 & 1,19 & 0,34 \\
\hline SITA & 497 & 0,43 & 0,03 & 5681 & 1,49 & 0,42 \\
\hline Telkom & 8654 & 7,48 & 0,56 & 40970 & 10,76 & 3,03 \\
\hline Transnet & 21438 & 18,52 & 1,39 & 65478 & 17,19 & 4,84 \\
\hline TOTAL & 115766 & 100,00 & 7,50 & 380822 & 100,00 & 28,13 \\
\hline *Note: SAA capex data onlyavailable for $2015 / 16$ financial years. Rand values are presented in \\
\hline nominal terms.
\end{tabular}

Sources: Own calculations using ACSA (2017); City Power (2017); CSIR (2017); Denel (2017); Eskom (2017); National Treasury (2019); PetroSA (2017); SAA (2016); SAPO (2017); SITA (2017); Telkom (2017) and Transnet (2018)

This scale of spending emphasises the sizeable role of the state in procuring goods and services from domestic and foreign private firms. Access to these contracts, and the facilitation of this access by corrupt officials, has been central to state capture in South Africa. As the country's two largest SOEs, both Eskom and Transnet have

1 According to the national government's website there are currently 171 public entities in South Africa at the national, provincial and municipal level (National Government, 2019). 
been crippled to an extent that now threatens their financial viability and capacity to manage substantial government-backed loans (of R350bn and R3.5bn, respectively) (National Treasury, 2018).

\subsection{TRANSNET'S SPENDING BOOM}

Over the last decade, one of the focal points of Transnet's business efforts has been increasing the capacity of its freight transport operations in order to meet an anticipated growth in demand (Transnet, 2018). This required a significant investment boost, and in 2012 the parastatal began a systematic programme of capital expansion, termed the Market Demand Strategy (MDS). The MDS was a R300bn, seven-year, capital investment plan with an overall operating budget of R420bn - designed to expand rail, port and pipeline infrastructure (PMG, 2015; Transnet, 2018). However, as we will discuss below, it coincided with billions of rands in corrupt deals at Transnet and massive kickback payments on many of the high-value procurement contracts signed during this period. As with Eskom, the considerable scale of the rents available through procurement spending made Transnet particularly attractive as a site for the theft of state funds (Eberhard \& Godinho, 2017).

Following its new procurement strategy, Transnet's annual capital expenditure increased rapidly - growing from R28.3bn in 2012 to R31.7bn in 2014 and reaching R36.4bn in 2015, which was the largest amount ever spent in a single year at Transnet (PMG, 2019). ${ }^{2}$ However, in 2016, the progressive spending began to falter for a number of reasons. From a financial perspective, there was a re-appraisal of the MDS given that the projected economic growth upon which it was modelled had not been realised (PMG, 2019). Over the next two years, capital spending decreased to pre2012 levels of around R20bn per annum. As a result, by 2018 only about half of the MDS budget had been spent, despite the strategy being in its final year (Transnet, 2018). This spending revision was not unexpected given that at the outset Transnet's underlying business case for the MDS does not appear to have fully assuaged doubts expressed by the National Treasury regarding its financial viability. In 2013, the then Minister of Finance, Pravin Gordhan, openly expressed his scepticism about the various growth and demand assumptions underpinning the MDS (Werksmans Attorneys, 2017). Gordhan was concerned that the project's profitability was reliant on Transnet's freight rail division experiencing growth in transported volumes in excess of GDP growth, and that a plan to introduce increased tariffs levied at above inflation in order to grow revenues was problematic (Werksmans Attorneys, 2017). It was also midway through 2016 that the first detailed reports of large-scale corruption at

2 Rand values are given in real, 2018 prices. 
Transnet began to make national headlines, ${ }^{3}$ and in November 2016 the SOE featured prominently in the Public Protector's State of Capture report (amaBhungane and Mail \& Guardian, 2016; Public Protector, 2016; Skiti \& Jika, 2016).

\subsection{HOW THE RENTS WERE ACCESSED}

Transnet's financial operations, including the MDS, were overseen by Mr Anoj Singh, Transnet CFO from 2009-2015. This period overlaps with what we identify as the financial high point of state capture - 2014 and 2015. Evidence suggests that, together with a network of individuals at the parastatal and the Guptas, prominent government official Singh used his control of financial procedures and a ballooning procurement budget to facilitate corruption on a grand scale. ${ }^{4}$ The first major move to facilitate access to the large rents available at Transnet, and the billions more to come, occurred in 2010, when Malusi Gigaba became the new Minister of Public Enterprises. This gave him oversight of the parastatal's management and top jobs, as well as detailed knowledge about the MDS and the spending increases it entailed (Bhorat, Buthelezi, Chipkin, Duma, Peter, Swilling \& Friedenstein, 2017). With Gigaba occupying a controlling position over Transnet, a string of new appointments to powerful positions began - ultimately putting crucial members of a state capture network in place (Pillay \& Prins, 2018). This began in earnest in 2011 with the unusually rapid appointment of Brian Molefe as Transnet CEO. Molefe had close connections with the Gupta family and in a pattern that soon became familiar, their family newspaper - The New Age predicted his appointment (Bhorat et al., 2017).

After being dismissed in 2010 for awarding irregular contracts, Siyabonga Gama was reappointed as the head of Transnet Freight Rail (TFR) in 2011 by a newly constituted Board under Molefe (Pillay and Prins, 2018; PMG, 2019). Then in August 2012, Iqbal Sharma, a well-known Gupta associate, was placed at the helm of the Board of Acquisitions and Disposals Committee (BADC) - a new Board established to oversee large infrastructure spending at the parastatal (Transnet, 2012; Bhorat et al., 2017). Sharma was also a business associate of Salim Essa, a central figure in the state capture web, who was paid billions of rands in kickbacks from Transnet deals between 2012 and 2016 (Bhardwaj, Sole \& Brümmer, 2014). Other senior Transnet employees linked to state capture include Stanley Shane, Phetolo Ramosebudi, Seth Radebe, and Richard Seleke (Pillay \& Prins, 2018).

3 Although detailed corruption allegations were already being published much earlier (see for example, Bhardwaj, Sole \& Brümmer, 2014).

4 Transnet has recently instituted criminal proceedings against Singh for his conduct and the South African Institute of Chartered Accountants (SAICA) has suspended him pending disciplinary action. He left Transnet and moved to Eskom, where he was suspended in 2017 and resigned in 2018. He has also been charged for misconduct at Eskom. 
Alongside others at Transnet, these men were the key actors in the looting that took place at Transnet, actively using their positions to enable dozens of corrupt deals, almost all of which have been connected back to the Gupta family network (Public Protector, 2016; Bhorat et al., 2017; Werksmans Attorneys, 2017). This facilitation of corruption includes manipulating management and financial procedures, establishing a culture of deception and mistrust at the parastatal, and sharing confidential information in order to ensure procurement contracts were awarded to firms that paid kickbacks to those in the network. Subsequent investigative reporting shows that the Guptas received kickbacks from at least seven large companies based on their contracts with Transnet (BizNews, 2017).

\subsection{TRANSNET-GUPTA INTERACTIONS}

Additional evidence of the Guptas' interest in Transnet, and their links to key Transnet Executives, emerged from correspondence contained in the so-called \#GuptaLeaks. This cache of leaked emails come from the Gupta-owned company Sahara, which functioned as an operational base for the family's state capture activities and contains detailed information about the network that developed around the Guptas from 20122016. Much of the incriminating evidence from the emails has already been reported on in detail, but the leak also contains data that offers up a timeline of interactions between the Gupta brothers and various government and SOE officials. ${ }^{5}$ What this reveals in the case of Transnet is how these interactions increase and overlap almost directly with the most damaging years of corruption at the parastatal. As we discuss below, estimates indicate that over R37bn was spent on deals linked to corruption at Transnet between 2013-2018, and nearly R8bn was paid to Gupta-linked firms in direct kickbacks. More specifically, the emails reveal how a private software firm with no formal links to the parastatal and no legitimate interest in its activities, or the large contracts it was securing with various international suppliers, was engaged in discussions about the parastatal and in direct contact with top Executives.

To examine the extent to which the Guptas discussed Transnet issues and to look more closely at their correspondence wih Executives at the SOE, we create a searchable database of the full email cache. This allows us to identify and examine conversations between various members of the Gupta family (via Sahara) and specific individuals at Transnet. In Figure 7.1 below, we use this information to produce a simple heat map that tabulates mentions of the word 'Transnet' in the leaked emails over time. We are then able to plot these mentions, which serve as a proxy for all the recorded email conversations taking place regarding the SOE.

5 For an overview of all investigative reporting from the \#GuptaLeaks, see https://www.guptaleaks.com/ 
The picture that emerges is a useful guide that aligns with the broader story of state capture at Transnet.

The horizontal lines in the figure represent the mean (average) and median number of times the word appears in the email cache over a four-year period. What is immediately clear is the spike in email discussions of Transnet issues in the Gupta archive from 2014 onwards. The box in the figure emphasises how the distribution of these mentions coincide both with the period of increased expenditure at the parastatal, as well as with the most financially destructive period of state capture. The median monthly word count is about 2.5 over the full period, but in mid to late 2014 this number increases to around 10, and in June of 2015 'Transnet' is mentioned 30 times in a single month, in separate email chains. On its own, this data is suggestive and presents circumstantial evidence of just how much attention the Guptas gave to Transnet, reflecting their indirect financial interest in key deals taking place at the SOE. This assertion aligns with a wealth of investigative reporting on the relationship between the Guptas and corrupt Transnet officials, and the looting they carried out. Indeed, recent court papers reveal in relative detail how kickbacks from Transnet deals were channelled to Sahara - as Comrie (2018a) reports, 98\% of Sahara's profits in June of 2015 came through illicit payments extracted from Transnet.

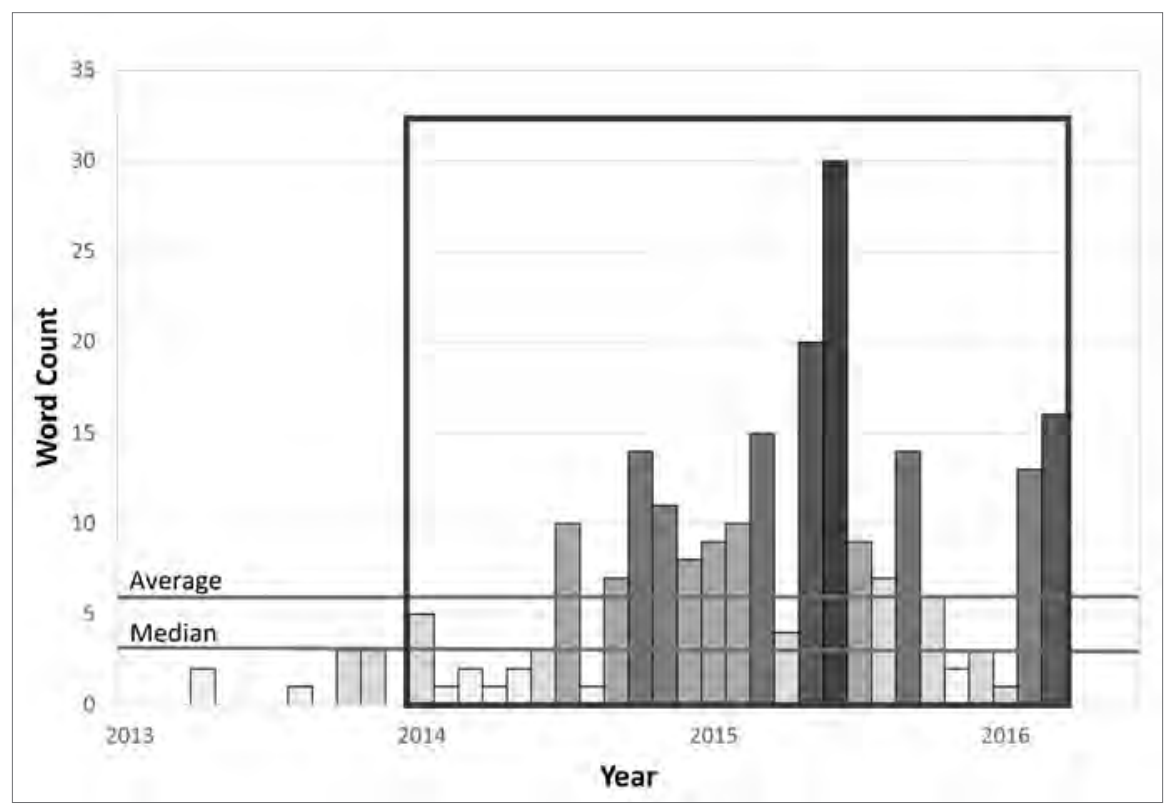

FIGURE 7.1 Heat map of Transnet mentions in the \#GuptaLeaks: 2013-2016 Source: \#GuptaLeaks (2017), own calculations

The contents of the emails in this edited archive, as well as attached documents and spreadsheets, are also indicative of the way in which Transnet Executives worked to facilitate corruption. Correspondence with the Guptas, and Managers at Sahara, include 
discussions of internal Transnet HR issues, minutes of Transnet Board meetings, specific procurement contracts now linked to corruption, tender documents, and the concerned sharing of newspaper articles exposing corruption at Transnet. ${ }^{6}$ For example, on 19 May 2014, Iqbal Sharma sent the draft agenda for a meeting of the $\mathrm{BADC}$ - the Board responsible for contracts dealing with large-scale infrastructure projects - to a Gupta family member. This was ahead of a meeting scheduled for 26 May 2014. The agenda noted that Anoj Singh was going to update the Board on the increase in the estimated total cost of a large locomotive procurement project - the purchase of 1064 locomotives - in which the overall costs had risen from R38bn to R54bn. To state the obvious, this is confidential information about a set of lucrative SOE contracts to which the Guptas should not have been privy. The timing of this exchange is also significant since it happened before the Board had met, giving the Gupta family prior knowledge of what would be discussed. This deal eventually resulted in kickback payments of R6.4bn going to Gupta-linked firms. The figure rises to just over R7bn if payments from consulting services, which helped to structure and inflate the locomotive deal, are included.

\subsection{THE COST OF STATE CAPTURE}

Over the course of 2013-2018, Transnet rapidly became ever more tangled in a vast web of corruption with costs that are far reaching and remain difficult to fully quantify. However, collating all the information currently in the public domain, we can establish an initial estimate of some of the major financial flows. We do this using data from a wide variety of sources including payments and contracts uncovered by investigative journalists, information contained in the \#GuptaLeaks, commissioned reports on Transnet produced by various government departments, Transnet financial statements, court documents, as well as evidence made available through the Zondo Commission. To foreground our two key results on the scale of the looting, Transnet spent a total of R37bn over the 2013-2018 period on contracts that had direct links to state capture, amounting to $60 \%$ of the company's capex and $10 \%$ of its total revenue over the same period. From these contract payments, we identify kickbacks totalling R7.7bn. ${ }^{7}$ These totals are as accurate as possible given the availability of information to date, but we caution that they are almost certainly underestimates. Some of the major tainted deals are briefly discussed from page 142 .

6 Several of the emails that provide clear evidence of corruption have been quoted and discussed at length in articles by amaBhungane and Scorpio (see amaBhungane \& Scorpio [2017a], for example).

7 The period for which we can identify contract values and payments to Transnet suppliers (2013-2018) differs from the period for which we can identify kickback payments (2012-2015). This is simply because our efforts at piecing together the underlying data only allow us insight into these timeframes. 


\section{CHASING THE MONEY TRAIN HOW THE SHADOW STATE INFILTRATED AND LOOTED TRANSNET}

\section{CORRUPTION NETWORK AND INDIVIDUALS}

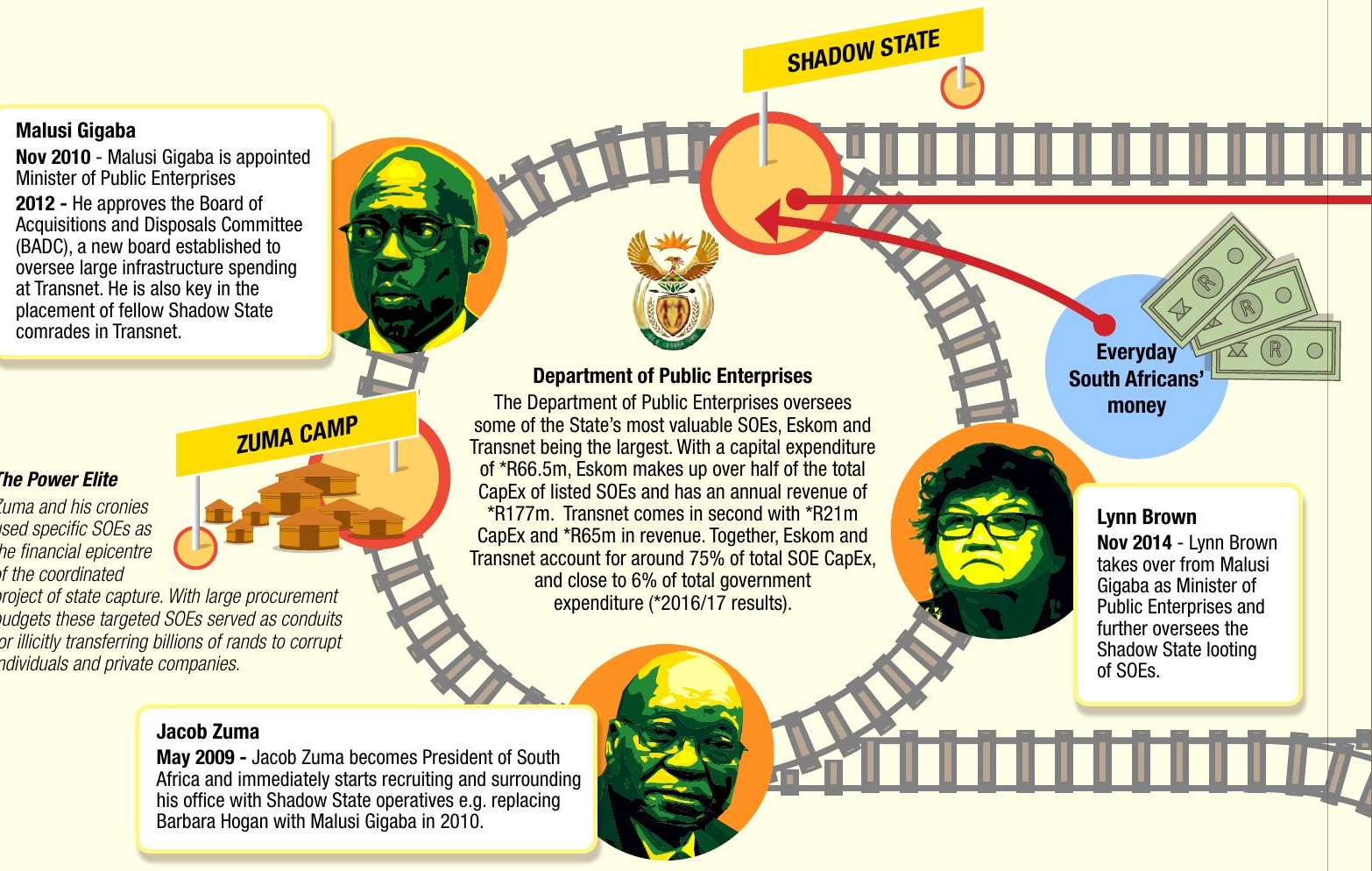

China South Rail \& China North Rail: 2012 to 2018 - Taking the lion's share of the 1259 locomotive contracts worth over R61.6bn, CSR \& CNR with the help of Regiments Asia and Trillian, redirected at least R7bn in public funds to Gupta-linked third parties.

SAP: 2015 - This German software company enlisted the services of 2 Guptalinked firms to secure an R800m contract with Transnet. In the end, SAP received R969m - R169m more than initially contracted, enabling kickbacks for the Guptas.

LIEBHERR: 2013 - 22 cranes were procured from Swiss-based company Liebherr. A South African, Gupta-linked front company was paid USD2.2m to secure Liebherr the contract.

ZPMC: 2012 - ZPMC was contracted to supply 7 port cranes for R650m. ZPMC agreed to pay a $13 \%$ 'finder's fee' to a Gupta-linked firm to secure the contract. The manipulation of the tender process saw ZPMC awarded the contract at an inflated value to account for the Gupta kickback.

NEOTEL: 2014 - The parastatal concluded several agreements with Neotel to provide CCTVs and other related services, which together totaled +/- R5bn. Millions of these rands were passed on to Gupta shell company Homix.

SOFTWARE AG: The company has denied knowledge of a contract with Transnet, or receiving any payments, but evidence shows that they were paid, and that they also paid kickbacks of R65m. 


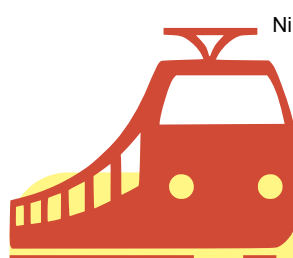

Nina Callaghan, Robyn Foley \& Mark Swilling (eds). Anatomy of State Capture. Stellenbosch: African Sun Media

\section{TIMELINE OF KEY EVENTS}

\section{Following the locomotive 'train wreck'}

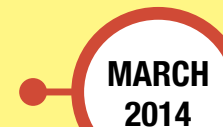

2014
17 Mar - Brian Molefe announces Transnet signed contracts with 4 separate suppliers for another 1064 locomotives. CSR and CNR due to supply 359 and 252 locomotives, respectively.
20 Mar - Guptas set up Venus shell company in UAE. 5 weeks later Venus is transfered into Singh's name.

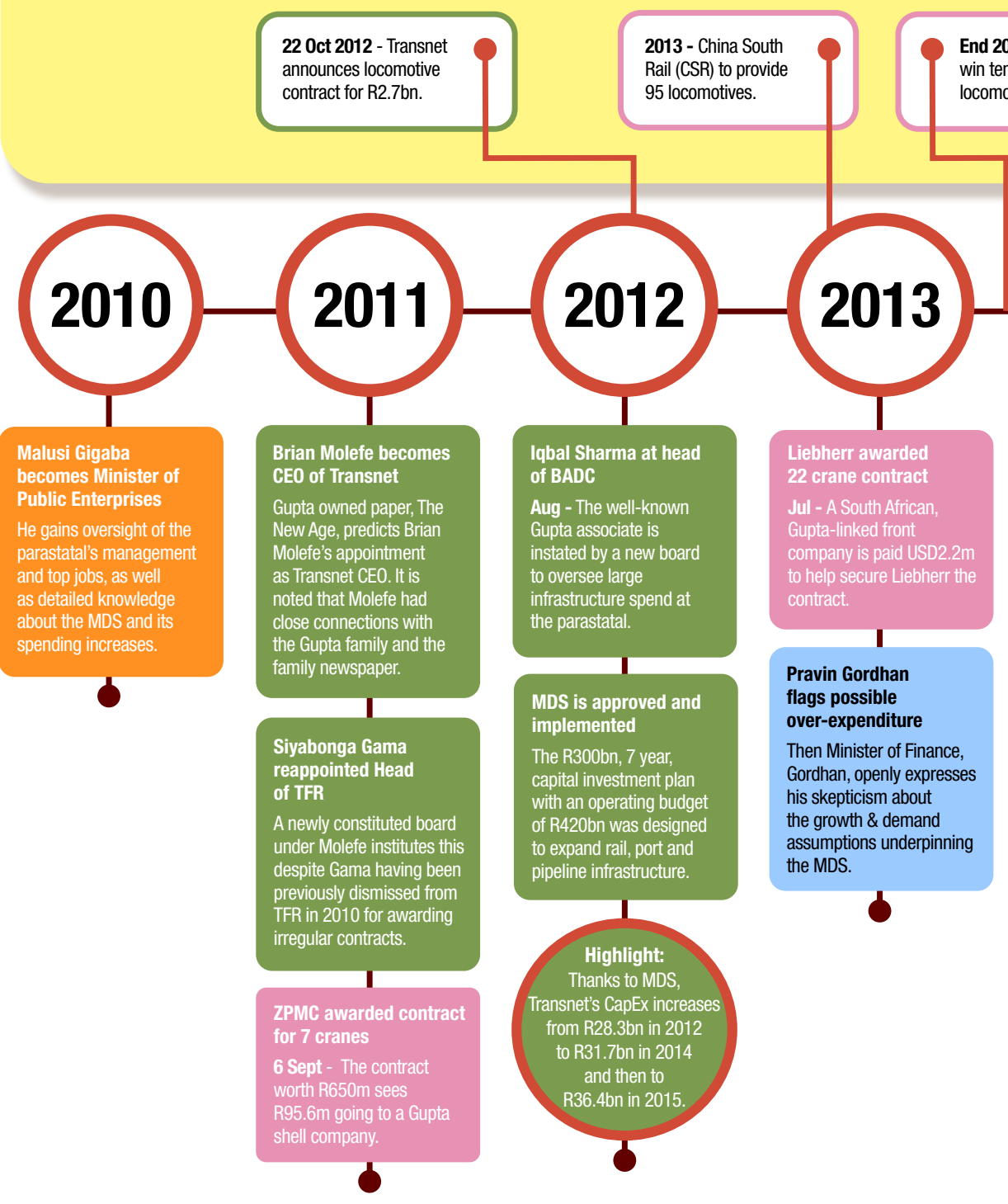

\section{UNIVERSAL GRAPHIC KEY}

The Shadow State Power elite

Corrupt, unethical companies

The Fixers and Enablers

The Brokers

In the public's interest

Highlights

Highlights

R46 million

Liebherr kickback

May - At least R46m ends

up in a Gupta company

in UAE from the 22 crane

Liebherr contract.

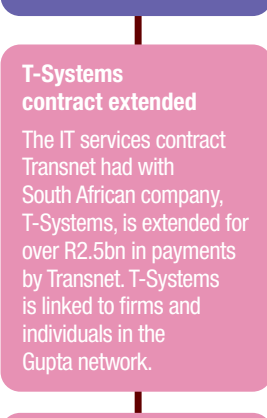

Transnet approves deals with Neotel

The CCTV and related services provided by Neotel cost Transnet almost R5bn. As before, there is no competitive tender process and kickback payments to several Gupta-linked firms are included 


\section{THE SYSTEMATIC CAPTURE AND LOOTING OF TRANSNET}

\section{How the money was extracted}

19 May - Iqbal Sharma sends the draft agenda for a BADC meeting scheduled for the following week (26 May) to a Gupta family member. The agenda notes a rand increase for the 1064 locomotives.
26 May - Overall procurement budget approved by the compromised BADC, ballooned by $43 \%$ (from R38.1bn to R54.5bn), undoubtedly to incorporate the kickbacks that CSR \& CNR had agreed to pay.

\section{5

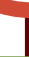

Molefe and Singh close in on Eskom

Apr - Brian Molefe

assumes CEO position at

Eskom. Anoj Singh takes

over as CFO of the new

cash cow in Jul 2015.

Siyabonga Gama takes

over as CEO of Transnet

and the pillaging of SA's

2 largest SOE coffers

continues.

Software AG \& GSS

pilot project

Transnet approves an

unsolicited proposal

from Software AG and

GSS (a Gupta company)

and enters into a pilot IT

project with them.

Evidence shows

kickbacks of R65m were

payed to the Guptas by

Software AG.

\section{1}

R800 million IT

Tender issued

Nov - The tender only

invited 1 bidder, SAP.

The German software

company enlisted the

services of two Gupta-

linked firms to secure

an $\mathrm{R} 800 \mathrm{~m}$ contract with

Transnet. In the end, SAP

received R969m -

$\mathrm{R} 169 \mathrm{~m}$ more than the

initial contracted amount,

the increase for kickbacks

to the Guptas.

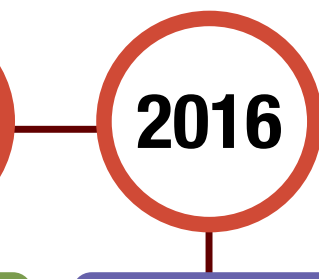

SAP pay R100 million

to Guptas

Apr to Dec - Payments

are made to CAD House

for landing them Transnet

Contracts. CAD House

distributes this to Sahara

Computers and others.

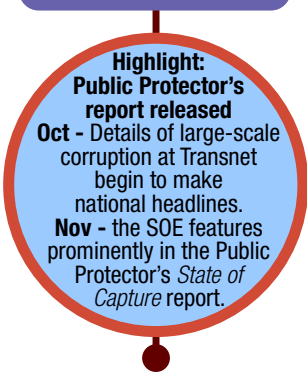

investigate Guptas
Oct - US and UK

authorities announce

that they will investigate

money-laundering and

corruption by the Guptas.

Werksmans

investigates allegations

Transnet hires law firm

Werksmans to investigate

media allegations of

impropriety linked

to procurements of the

1064 locomotives.

\#GuptaLeaks come out surface in public.

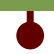

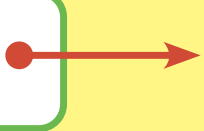

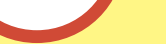

2018

Height

of looting

2013-2018

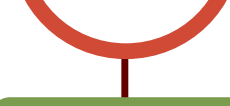

Werksmans report

over-ridden

Before Siyabonga Gama

is booted out as CEO,

Transnet calls the

Werksmans report

"inconclusive" and

declines to act on its

recommendations.
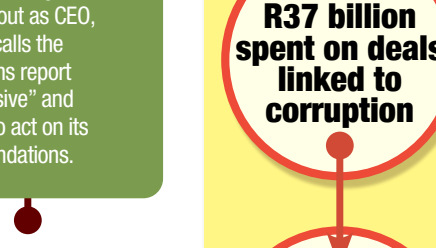

REFERENCES AND ACKNOWLEDGMENTS:

Development Policy Research Unit (2019) 'State Capture and the Economics of Corruption: The Case of Transnet', unpublished working paper, DPRU, University of Cape Town, South Africa.

Pillay, D. and Prins, N (2018) Transnet Inquiry Reference Book State Capacity Research Project Cape Town: Public Affairs Research Unit Available at:

hittps://sastatecapture.org.za/site/files/documents/151/02. Transnet_Inquiry_Refer-

State Capacity Research Project (2017) Betrayal of the Promise: How South Africa is being stolen, State Capacity Research Project. South Africa. Available at: hittp://markswilling.co.za/wp-content/uploads/2017/05/25052017-Betrayal-of-the-Promise.pdf.

- Investigative Journalists that unpack the \#GuptaLeaks. Available at: hittps://www. gupta-leaks.com/category/transnet-2/

- Daily Maverick's Scorpio. Available at:

https://www.dailymaverick.co.za/section/scorpio/\#gsc.tab=0

- amaBhungane. Available at:

https://amabhungane.org/stories/special-report-the-guptaleaks-and-more-all-

our-stories-on-state-capture-2

News24. Available at:

hittps://www.news24.com/ 
As alluded to above, the launch of the MDS represented a major opportunity for state capture. One of the earliest sizeable capital investment deals tainted by corruption at Transnet was for the supply of port cranes in 2012. The contracted company, ZPMC, had agreed to pay a $13 \%$ 'finder's fee' to a Gupta-linked firm in order to secure the contract (\#GuptaLeaks, 2017). The resultant manipulation of the tender process saw ZPMC awarded the contract at an inflated value that incorporated the kickback, which was to be paid to the Gupta firm over the next two years (amaBhungane \& Scorpio, 2017a). This practice of absorbing illicit payments into the estimated total cost of large contracts at Transnet continued for several years, with the Guptas being primary beneficiaries. Procurement corruption is of course a problem at many SOEs, but the events at Transnet were unique given the level of sophistication, scale and near total monopolisation of control at the parastatal during the heady days of intense and pervasive state capture. As the emails suggest, and our data below confirms, this form of corruption became more lucrative over time as existing procurement procedures and mechanisms in place to prevent corruption were routinely overridden. After the deal with ZPMC, a similar process followed in 2013, when 22 cranes were procured from the Swiss-based company Liebherr. A South African, Gupta-linked front company was paid USD2.2m in order to secure Liebherr the contract (\#GuptaLeaks, 2017).

The corruption involved in these two crane deals is overshadowed by the events surrounding the procurement of over a thousand locomotives at Transnet, beginning in 2012 but reaching a highpoint in 2014. Two separate deals concluded in 2014, with two Chinese companies, involved payments totalling almost R25bn, with kickbacks to the Gupta network accounting for a staggering 25\% of this. In financial terms, these locomotive deals were by far the most brazen and lucrative operation for the Gupta network. Transnet first contracted with one of these suppliers - China South Rail (CSR) - in 2012 to provide 95, and later another 100, locomotives. Both contracts were awarded through a process of confinement, which bypassed competitive tender procedures - a popular strategy to control which firms were awarded contracts at Transnet and also used at other SOEs (Fundudzi Forensic Services, 2018). Two years later, Transnet signed contracts with four separate suppliers for another 1064 locomotives. CSR and China North Rail (CNR) were due to supply 359 and 252 locomotives, respectively. The overall procurement budget, approved by the compromised BADC, had ballooned by $43 \%$ (from R38.1bn to R54.5bn), in all likelihood to incorporate the kickbacks that both CSR and CNR had agreed to pay. ${ }^{8}$ 
Kickbacks and corruption on a smaller financial scale also extended to key consulting services that Transnet procured to assist with its costly capital investment plans. In 2014, a firm called Regiments Capital became involved in consulting at Transnet (Pillay \& Prins, 2018). Regiments had pre-existing links with several corrupt bureaucrats, as well as the Guptas, and began to use its influence to extract exorbitant rents from the parastatal. While the size of the contracts do not compare to the locomotive deals, the relative amounts that were paid onwards in kickbacks is stunning. In one instance, Salim Essa was paid a R50m finder's fee for securing Regiments a contract with Transnet, and during its engagements with the parastatal Regiments routinely paid kickbacks of up to $50 \%$ of its contract earnings to Gupta-linked firms (Comrie, 2018b). A similar role was played by Trillian, a separate consulting firm set up by Essa that eventually took over from Regiments and was awarded several lucrative Transnet contracts (Comrie, 2018b). Together Regiments and Trillian were paid R1.1bn by Transnet, and R615m of this was paid out by them in kickbacks - amounting to 56\% of their total earnings. We view the consulting services component of state capture at Transnet as the generator of regular cash flow to these entities, whilst they worked on the longer-run aim of securing larger illicit gains from procurement contracts at Transnet and other SOEs.

As the circumvention of established procurement processes became more widespread at Transnet, and the Gupta-linked network gained increasing control, contracts in other areas of the company were targeted. SAP, a German software company, enlisted the services of two Gupta-linked firms to secure an R800m contract with Transnet (Pillay \& Prins, 2018). In the end, SAP received R969m - R169m more than the initially contracted amount - with the increase accounting for the kickbacks due to the Guptas. SAP subsequently made a public apology for their role in state capture at Transnet (Daily Maverick, 2017). Another German company, Software AG, was engaged in a similar strategy with the same Gupta-linked firms. The company has denied knowledge of a contract with Transnet, or receiving any payments, but evidence shows that they were paid, and that they also paid kickbacks of R65m (amaBhungane \& Scorpio, 2017a).

Other large contracts involving corruption at Transnet implicate a number of additional service providers. In 2014, the parastatal concluded several agreements with Neotel to provide CCTV and other related services, which together totalled almost R5bn (Brümmer, Comrie \& Sole, 2016). Again, these were typically awarded without a competitive tender process and included kickback payments to several Gupta-linked firms (Brümmer, Comrie \& Sole, 2016). The extension of an IT services contract with the South African company, T-Systems, also in 2014, led to payments from Transnet of over R2.5bn (Pillay \& Prins, 2018). Again, there is evidence linking T-Systems to 
firms and individuals in the Gupta network, the payment of kickbacks and, according to a Transnet source, the extension of the T-Systems contract in question "bypassed every process that exists in Transnet" (Pillay \& Prins, 2018, p. 30).

To summarise the financial information linked to these various tainted deals at Transnet, we combine the data and present it in Figures 7.4 and 7.5 below. The figures are our best efforts to track the payments made by Transnet, and the illicit proceeds from these payments, over the 2012-2018 period. $^{9}$ Figure 7.4 plots the amount received by firms engaged in tainted deals with the parastatal - that is, contracts in which there is evidence of kickbacks being paid to third parties, while Figure 7.5 shows what proportion of these payments were passed on as direct kickbacks to firms or individuals. ${ }^{10}$

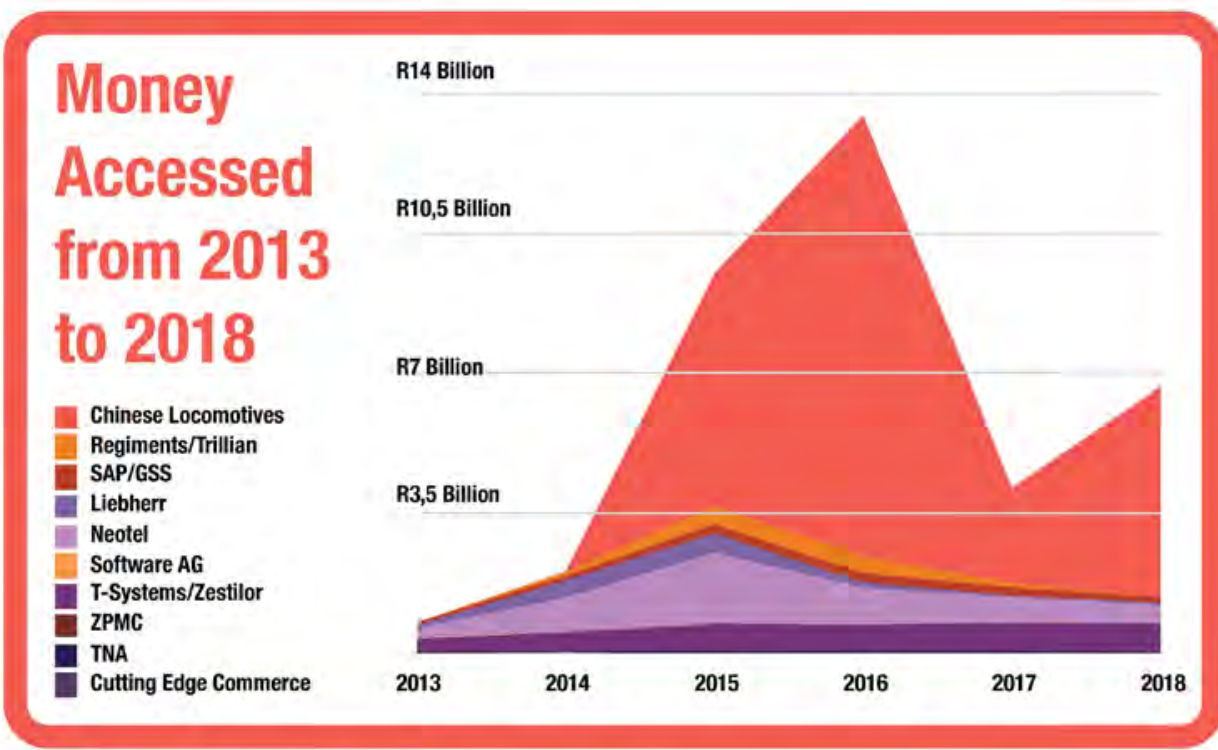

FIGURE 7.4 Tainted Deals by Supplier: Rbn, 2013-2018

Sources: \#GuptaLeaks (2017); amaBhungane \& Scorpio (2017a, 2017b); BizNews (2017); Brümmer, Comrie \& Sole (2016); Comrie (2018b); Fundudzi Forensic Services (2018); Pillay and Prins (2018); Bhorat et al. (2017); Sole (2018)

What is immediately clear from Figure 7.4 is that the height of state capture at Transnet, purely in terms of the value of tainted contracts, was 2014-2016. This includes contracts with Neotel, Liebherr, SAP, Regiments, and Trillian. However, the largest spike in tainted contract payments over the period comes from the locomotive

9 We are unable to accurately deflate many of the illicit payments given the numerous and incomplete sources of data and the fact that we cannot accurately identify exact payment dates in many cases. As a result, all figures presented here are in nominal terms.

10 For Figure 7.5 our timeline ends in 2015 as we could not find verifiable evidence of new kickback payments beyond this date. 
deal and payments made to both CSR and CNR. In Figure 7.5, we see the dominance of the kickbacks from these two locomotive contracts - together with the associated consulting services they account for over $90 \%$ of all kickbacks for which we can find data. Together then CSR, CNR, Regiments and Trillian are responsible for illicitly re-directing a total of at least R7bn in public funds to Gupta-linked third parties. Indeed, the consulting contracts with Regiments and Trillian, which were initially set up around this deal, but later extended into other areas of Transnet's operations, account for the second largest share of the total kickbacks.

\section{Kickbacks}

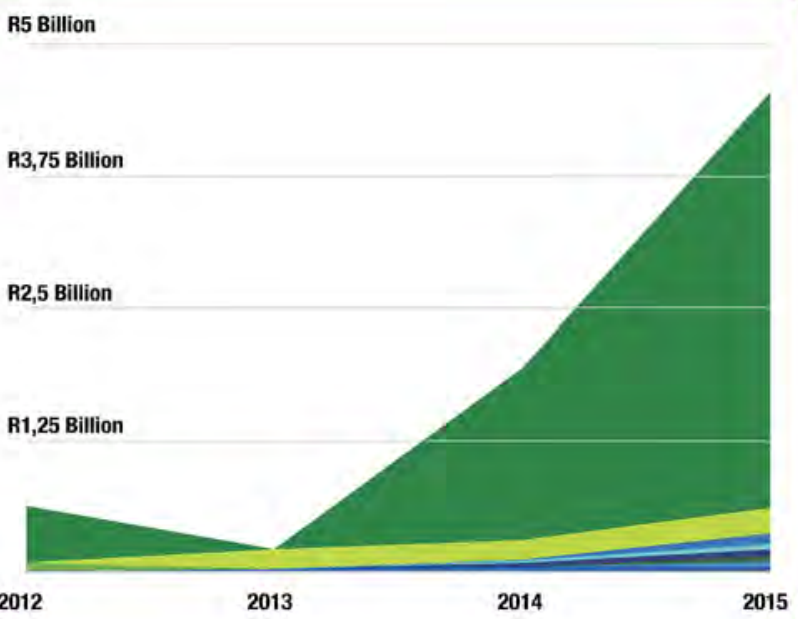

paid out

from 2013 to 2015

Chinese Locomotives

Regiments/Trillian

SAP/GSS

Liebherr

Neotel

Software AG

T-Systems/Zestilor

ZPMC

TNA

Cutting Edge Commerce

2012

2013

2014

2015

FIGURE 7.5 Kickbacks by Supplier: Rbn, 2013-2015

Sources: \#GuptaLeaks (2017); amaBhungane \& Scorpio (2017a, 2017b); BizNews (2017);

Brümmer, Comrie \& Sole (2016); Comrie (2018b); Fundudzi Forensic Services (Fundudzi

Forensic Services, 2018); Pillay and Prins (2018); Bhorat et al. (2017); Sole (2018)

\subsection{FOLLOWING KICKBACKS FROM THE CHINESE LOCOMOTIVE DEALS}

In a final effort to examine what happened at Transnet, and where these billions of rands in stolen funds went, others have been able to follow some of the kickbacks paid by CSR and CNR for at least one additional step (Sharife, 2017). This provides a basic insight into how the Guptas' state capture network got their illicit funds out of the country and made the money flows nearly impossible to trace.

The vast majority of the locomotive kickbacks shown above were paid to two companies set up in Hong Kong by Salim Essa (Sharife, 2017). Indeed, data show that between 2015 and 2017, CSR and CNR paid a total of R3.3bn to Tequesta, and R840m to Regiments Asia. This positions these two companies set up by Essa at the heart of all 
the kickbacks paid on tainted deals at Transnet. Evidence in the \#GuptaLeaks indicates that the two companies were registered on the same day and share a physical address, but they appear to do no independent business. Bank statements show that their only source of income is from the CSR and CNR payments, and their only activity appears to be channelling this money onwards to dozens of shell companies around the world. The payments from CSR and CNR to Tequesta and Regiments Asia were made in a few large tranches, ranging from USD2m to USD11m at a time.

As has been reported, in the days after payments were received by Essa's companies, the money would then leave the accounts in many, much smaller transactions crediting the accounts of unknown shell companies in various financial jurisdictions including China, Dubai, and the United Arab Emirates. Over a two-year period, Tequesta made 244 separate payments that range in value from around USD4 400 to USD600000, with a mean value of approximately USD250 000. There is little doubt that the companies simply acted as a vehicle to move the illicit funds out of South Africa and thus limit the possibility of tracing the money. The sequence is the same each time: A large kickback payment is paid from CSR and CNR, and within several days almost all the money is sent on in smaller payments. It is unclear if HSBC, the bank with which Essa opened his company's accounts, notified South African or any other financial authorities about the suspicious transactions.

The picture that emerges from the payments made by CNR and CSR to Tequesta and Regiments Asia certainly fits a common pattern of money laundering. And the use of Hong Kong as a financial jurisdiction for companies with no business interest there is an obvious warning sign that suggests an attempt to avoid investigation by South African authorities. In addition, the structure of the money flows fits a classic money laundering cycle that is common globally and makes the money virtually impossible to trace (FATF, 2009).

This is then the final stage of a state capture project: how to hide the stolen funds. In this regard, several key features are clear. Firstly, the kickbacks are laundered to overseas accounts outside of South Africa, making the funds difficult to trace. Secondly, multiple firms are used in this process. Thirdly, once received, payments are sent onwards to dozens of other accounts in several repeat payment periods. And again, these accounts are in multiple financial jurisdictions, which makes tracking these funds as they scatter around the world in this way, virtually impossible.

What then has been the ultimate impact on a project when billions of rands go towards kickbacks instead of funding the project itself? Perhaps unsurprisingly, in the case of CSR or CNR, neither has delivered on their contract with Transnet. Table 7.2 shows where locomotive delivery stood in December 2018. The contracts were signed in 
2014 and fulfilment of the terms was expected in three years. CSR has delivered just over half of its contracted number of locomotives - 208 out of an expected 359, with $42 \%$ still outstanding. CNR has only supplied 21 out of an expected 232 trains, with 91\% outstanding. Moreover, contractual agreements with both CSR and CNR around local content use, which specified that a certain proportion of the trains had to be manufactured locally, have not been honoured (Fundudzi Forensic Services, 2018).

TABLE 7.2 Expected and Actual Delivery, Chinese Locomotive Suppliers: 2018

\begin{tabular}{|l|c|c|c|}
\hline Supplier & $\begin{array}{c}\text { Contracted Delivery } \\
\text { Number in 2015 }\end{array}$ & $\begin{array}{c}\text { Actual Delivery } \\
\text { Number in 2018 }\end{array}$ & $\begin{array}{c}\text { \% Locomotives } \\
\text { Outstanding }\end{array}$ \\
\hline China South Rail (CSR) & 359 & 208 & 42 \\
\hline China North Rail (CNR) & 232 & 21 & 91 \\
\hline
\end{tabular}

Source: PMG (2018b)

\subsection{CONCLUDING REMARKS}

The failed locomotive procurement deal at Transnet, spanning the period 2012-2018, serves as one of the clearest examples of how state capture broke down systems of control and oversight at a key SOE in South Africa. Transnet was successfully infiltrated by a network of corrupt individuals at upper management levels - from the Minister of Public Enterprises to the CEO, including specific Executive Committee Members. Corrupt individuals were placed in strategic positions with substantial discretionary power, which then facilitated the creation and extraction of massive rents. The productive use of state funds was soon supplanted by a well-organised, corrupt network focused purely on rent-seeking activities. This was accomplished through the hijacking of the procurement process, re-orientating it away from its legitimate operation towards a rubber-stamping activity arranged behind closed doors by members of a state capture network.

The immense scale of state capture detailed here was made possible by the appointment of an array of corrupt individuals to key positions within the governing structure at Transnet. For example, the appointment of Brian Molefe to the position of CEO facilitated the sign-off on the excessive contract inflations and amendments to the 1064 locomotive deal that were not approved by the parastatal's Board. This essentially generated the kickbacks paid to Tequesta and Regiments Asia, which have now disappeared into an untraceable international financial web. Billions of rands in state funds were stolen and most were then moved offshore in a dedicated money laundering operation, with enormous welfare costs for South Africa. Alongside Molefe, other members of the state capture network at Transnet held significant levels of discretionary power across a variety of functions, from business operations to 
regulatory oversight. The parastatal has now instituted criminal proceedings against many of those involved. The scale of the theft, the way it affected all spheres of operations at Transnet, and the patently obvious negligence of correct contracting procedure associated with these deals, are evidence of how state capture can blend formalised institutional protection and procurement corruption to result in breathtaking levels of financial and governance misconduct - and all at an institution so central to South Africa's growth and development trajectory. 


\section{References}

ACSA (Airports Company South Africa) (2017) Consolidated Annual Financial Statements 2016/17. South Africa: Airports Company South Africa.

amaBhungane \& Mail \& Guardian (2016)

'Gupta-linked company set to score R800million in Transnet IT solution tender deal', Mail \& Guardian. [Online]. https://bit.ly/ 3yzAmak

amaBhungane \& Scorpio (2017a) ‘ $\#$ GuptaLeaks: Another German software giant implicated in 'kickback' payments', Daily Maverick. [Online].https://bit.ly/2VxfgeB

amaBhungane \& Scorpio (2017b) '\#GuptaLeaks: How Anoj Singh sang for his supper', Daily Maverick. [Online]. https://bitly/3fDPvQM

Bhorat, H., Buthelezi, M., Chipkin, I., Duma, S., Mondi, L., Peter, C., Qobo, M., Swilling, M. \& Friedenstein, H. (2017) Betrayal of the Promise: How South Africa is being stolen, State Capacity Research Project. [Online]. https://bit.ly/3CmP5rL

Bhardwaj, V., Sole, S. \& Brümmer, S. 2014. 'Transnet tender boss's R50-billion double game', Mail \& Guardian. [Online] https://bit. ly/3rYf Yxj (Accessed 20 June 2021).

BizNews (2017) 'Naming, shaming 7 big companies that SECRETLY shared Transnet billions with Gupta fronts.' [Online] https:// bit.ly/3ylzekI

Brümmer, S., Comrie, S. \& Sole, S. (2016) 'Exclusive: Guptas 'Laundered' kickbacks - here's the evidence', Mail \& Guardian. [Online]. https://bit.ly/2X6ZJmf

City Power (2017) Annual Integrated Report 2016/17. South Africa: City Power.

Comrie, S. (2018a) ‘Guptas Siphoned R100mplus from China loan, evidence shows', Daily Maverick. [Online] https://bit.ly/3fZK1A3

Comrie, S. (2018b) 'The Trojan horse that wheeled R600m out of state-owned entities', Daily Maverick. https://bit.ly/3slu7cZ (Accessed 11 September 2020).

CSIR (Council for Scientific and Industrial Research) (2017) Annual Report 2016/17. South Africa.
Daily Maverick (2017) 'Newsflash: SAP takes disciplinary action, calls in US authorities, amid \#Gupaleaks corruption revelations'. [Online]. https://bit.ly/2U22nbN (Accessed 7 August 2020)

Denel (2017) Denel Integrated Report 2016/17. [Online].https://bit.ly/2TToeC1

Eberhard, A. \& Godinho, C. (2017) Eskom Inquiry Reference Book, State Capacity Research Project. Cape Town. [Online]. https://bitly/3An5ri0

Eskom (2017) Integrated Report 2016/17. South Africa: Eskom.

FATF (Financial Action Task Force) (2009) AML/CFT evaluations and assessments: handbook of countries and assessors. Paris.

Freund, B. (2018) Twentieth-Century South Africa. Cambridge: Cambridge University Press. https://doi.org/10.1017/ 9781108604222

Fundudzi Forensic Services (2018) ‘Chapter I: Final Report: Forensic Investigation Into Various Allegations At Transnet', National Treasury. [Online]. https://bit.ly/3fIH5Y9

\#GuptaLeaks (2017) \#GuptaLeaks. [Online]. https://www.gupta-leaks.com/ (Accessed 10 November 2017).

National Government (2019) Public Entities. [Online].https://bit.ly/3xpVuyw

National Treasury (2018) Budget Review 2018. Pretoria: Government Printers.

National Treasury (2019) Budget Review 2019. Pretoria: Government Printers.

PetroSA (2017) Integrated Annual Report 2016/17. South Africa.

Pillay, D. \& Prins, N. (2018) Transnet Inquiry Reference Book, State Capacity Research Project. Cape Town: Public Affairs Research Unit. [Online]. https://bit.ly/3An64Io

PMG (Parliamentary Monitoring Group) (2015) Transnet Market Demand Strategy. NCOP Public Enterprises and Communication, 10 June.

PMG (Parliamentary Monitoring Group) (2018a) Eskom Inquiry: Malusi Gigaba. [Online].https://pmg.org.za/page/MGigaba (Accessed 7 August 2020). 
PMG (Parliamentary Monitoring Group) (2018b) Local public procurement in the transport industry: Department briefing; 1064 Locomotives contract: Transnet update. [Online].https://bit.ly/3jEiLYS (Accessed 7 August 2020).

PMG (Parliamentary Monitoring Group) (2019) Transnet market demand strategy implementation. https://bit.ly/3fHy4P8

Public Protector (2016) State of Capture, Public Protector. Pretoria. [Online]. https://bit.ly/ 3AjUXQp (Accessed 1 September 2018).

SAA (South African Airways) (2016) Integrated Annual Report 2015/16. South Africa: South African Airways.

SAPO (South African Post Office) (2017) Financial Statements 2016/17. South Africa: South African Post Office.

Sharife, K. (2017) 'Guptas, Big Banks Linked to South African-Chinese Locomotive Deal', Organized Crime and Corruption Reporting
Project (OCCRP). [Online]. https://bit.ly/ 3xv9c36 (Accessed 4 December 2019).

SITA (State Information Technology Agency) (2017) Annual Report 2016/17. South Africa: State Information Technology Agency. Skiti, S. \& Jika, T. (2016) 'Transnet deals fall into Gupta man's lap', Sunday Times. [Online]. https://bit.ly/3AndPOW

Sole, S. (2018) 'The "Gupta Minyan" and the R647m Transnet scam', Daily Maverick. [Online]. https://bit.ly/3fD2EJG

Telkom (2017) Group Results 2016/17. South Africa: Telkom.

Transnet (2012) Transnet Integrated Report 2012. Johannesburg: Transnet.

Transnet (2018) Integrated Report 2017/18. South Africa: Transnet.

Werksmans Attorneys (2017) Acqusition of 1064 locomotives for Transnet's general freight business, Organisation Undoing Tax Abuse (OUTA). [Online]. https://bit.ly/3ltT7IE 


\section{APPENDIX}

\begin{tabular}{|c|c|c|c|c|}
\hline $\begin{array}{l}\text { Case Study } \\
\text { in State } \\
\text { Capture }\end{array}$ & Status & Summary Description & $\begin{array}{l}\text { Investigation } \\
\text { Body / } \\
\text { Source of } \\
\text { Evidence }\end{array}$ & $\begin{array}{l}\text { Government } \\
\text { Entity } \\
\text { Implicated }\end{array}$ \\
\hline \multicolumn{5}{|c|}{ Scandals Connected to Jacob Zuma, Guptas, Other Key Networks and ANC Politics } \\
\hline $\begin{array}{l}\text { The State } \\
\text { of Capture } \\
\text { report - } \\
\text { focuses } \\
\text { on Guptas' } \\
\text { relationship } \\
\text { with Jacob } \\
\text { Zuma and } \\
\text { their alleged } \\
\text { influence on } \\
\text { the affairs } \\
\text { of state }\end{array}$ & $\begin{array}{l}\text { First complaint } \\
\text { was received } \\
\text { in March } 2016 \\
\text { and the report } \\
\text { was released in } \\
\text { November } 2016 .\end{array}$ & $\begin{array}{l}\text { Investigation into complaints of alleged improper } \\
\text { and unethical conduct by the President and } \\
\text { other State Functionaries, relating to alleged } \\
\text { improper relationships and involvement of the } \\
\text { Gupta Family in the removal and appointment } \\
\text { of Ministers and Directors of State-Owned } \\
\text { Enterprises (SOEs), resulting in improper and } \\
\text { possibly corrupt award of State Contracts and } \\
\text { Benefits to the Gupta Family's Businesses. } \\
\text { The report details numerous allegations of } \\
\text { the Guptas' involvement in affairs of the state } \\
\text { and their irregular activities that enable rent } \\
\text { extraction. The findings were not conclusive } \\
\text { and the remedial action was to establish a } \\
\text { commission of inquiry into state capture (to } \\
\text { be appointed by the President, but with a } \\
\text { judge selected by the Chief Justice). Litigation } \\
\text { endeavoured to delay or prohibit the report's } \\
\text { release and implementation of remedial actions, } \\
\text { but failed, and the commission was established } \\
\text { in } 2018 \text {. }\end{array}$ & $\begin{array}{l}\text { - Public } \\
\text { Protector, } \\
\text { followed by } \\
\text { litigation }\end{array}$ & $\begin{array}{l}\text { - GCIS (The } \\
\text { New Age) } \\
\text { - Eskom } \\
\text { (Optimum) } \\
\text { - Transnet } \\
\text { (Regiments/ } \\
\text { Trillian) } \\
\text { - Denel } \\
\text { - SAA (The } \\
\text { New Age) } \\
\text { - SABC (The } \\
\text { New Age) } \\
\text { - Department of } \\
\text { Finance } \\
\text { - Transport } \\
\text { (SAA) } \\
\text { - Communica- } \\
\text { tions (SABC } \\
\text { \& GCIS) }\end{array}$ \\
\hline $\begin{array}{l}\text { Zondo } \\
\text { Commission }\end{array}$ & $\begin{array}{l}\text { Established } \\
\text { in 2018, with } \\
\text { anticipated } \\
\text { conclusion being } \\
\text { the end of } 2021 .\end{array}$ & $\begin{array}{l}\text { Formally titled the Judicial Commission of } \\
\text { Inquiry into Allegations of State Capture, } \\
\text { Corruption and Fraud in the Public Sector } \\
\text { including Organs of State, the Commission } \\
\text { was promulgated by then President Zuma in } \\
\text { response to the remedial actions as outlined in } \\
\text { the Public Protector's State of Capture report. } \\
\text { As of June } 2021 \text {, the Commission that started } \\
\text { in August } 2018 \text { has held more than } 418 \text { days } \\
\text { of hearings of over } 330 \text { testimonies (generating } \\
\text { over } 71000 \text { pages of transcript). The inquiry's } \\
\text { terms of reference were expansive and, as } \\
\text { such, the scope of investigations went beyond } \\
\text { merely looking into the Gupta-related cases, } \\
\text { covering other networks (e.g., Bosasa) as well } \\
\text { as other government institutions (e.g., role } \\
\text { of Parliament). }\end{array}$ & $\begin{array}{l}\text { - Zondo } \\
\text { Commission }\end{array}$ & $\begin{array}{l}\text { Various } \\
\text { work-streams } \\
\text { covering } \\
\text { inter alia: } \\
\text { - SOEs } \\
\text { (Eskom, } \\
\text { Transnet, } \\
\text { Denel, SAA) } \\
\text { - Free State } \\
\quad \text { Provincial } \\
\text { Government } \\
\text { - Bosasa } \\
\text { - SARS } \\
\text { - Law } \\
\text { enforcement } \\
\text { - State Security } \\
\text { Agency (SSA) } \\
\text { - The New Age } \\
\text { \& ANN7 } \\
\text { - Role of } \\
\text { Parliament } \\
\text { and ANC }\end{array}$ \\
\hline
\end{tabular}




\begin{tabular}{|c|c|c|c|c|}
\hline $\begin{array}{l}\text { Case Study } \\
\text { in State } \\
\text { Capture }\end{array}$ & Status & Summary Description & $\begin{array}{l}\text { Investigation } \\
\text { Body / } \\
\text { Source of } \\
\text { Evidence }\end{array}$ & $\begin{array}{l}\text { Government } \\
\text { Entity } \\
\text { Implicated }\end{array}$ \\
\hline \multicolumn{5}{|c|}{ Scandals Connected to Jacob Zuma, Guptas, Other Key Networks and ANC Politics } \\
\hline Bosasa & $\begin{array}{l}\text { Dating back to a } \\
2009 \text { SIU report. } \\
\text { Investigations and } \\
\text { various litigations } \\
\text { are ongoing. }\end{array}$ & $\begin{array}{l}\text { In 2019, former Bosasa C00, Anglo Agrizzi, } \\
\text { testified at the Zondo Commission, detailing } \\
\text { the acts and long history of corruption between } \\
\text { various Bosasa companies predominantly } \\
\text { owned by Gavin Watson, and numerous } \\
\text { government entities/departments. The } \\
\text { testimony of Agrizzi (and other former Bosasa } \\
\text { employees) corroborated the findings of a } \\
2009 \text { SIU investigation that alleged corruption } \\
\text { in several contracts Bosasa had with the } \\
\text { Department of Correctional Services. Criminal } \\
\text { court proceedings have been initiated based } \\
\text { on the } 2009 \text { SIU investigation, along with new } \\
\text { investigations initiated by SARS and other law } \\
\text { enforcement entities. }\end{array}$ & $\begin{array}{l}\text { - Special } \\
\text { Investi- } \\
\text { gation } \\
\text { Unit (SIU) } \\
\text { - Zondo } \\
\text { Commission }\end{array}$ & $\begin{array}{l}\text { - Department of } \\
\text { Correctional } \\
\text { Services } \\
\text { - Department of } \\
\text { Justice } \\
\text { - Department of } \\
\text { Home Affairs } \\
\text { - Department of } \\
\text { Transport } \\
\text { - Various SOEs } \\
\text { (e.g., SAPO, } \\
\text { ACSA) } \\
\text { - National } \\
\text { Prosecuting } \\
\text { Authority } \\
\text { (NPA) } \\
\text { - Members of } \\
\text { Parliament }\end{array}$ \\
\hline Arms Deal & $\begin{array}{l}\text { Various } \\
\text { investigations and } \\
\text { sources, dating } \\
\text { back to 1990s. } \\
\text { Most significant } \\
\text { source being } \\
\text { through Seriti } \\
\text { Commission. } \\
\text { Corruption case } \\
\text { against Zuma is } \\
\text { ongoing. }\end{array}$ & $\begin{array}{l}\text { Commission of Inquiry into allegations of fraud, } \\
\text { corruption, impropriety, or irregularity in the } \\
\text { Strategic Defence Procurement Packages } \\
\text { (SDPP). Various court cases related to } \\
\text { allegations of corruption against Jacob Zuma. } \\
\text { On Monday, } 24 \text { October 2011, the President } \\
\text { announced the Commission chaired by Judge } \\
\text { Seriti. The findings of the Commission were that } \\
\text { there was "no evidence" of corruption, but this } \\
\text { is seen by many to have been a whitewash. The } \\
\text { report was taken on review and set aside in } \\
\text { August } 2019 \text {. The corruption case against Zuma } \\
\text { is ongoing before the courts. }\end{array}$ & $\begin{array}{l}\text { - Seriti } \\
\text { Commission } \\
\text { - Various } \\
\text { court cases }\end{array}$ & $\begin{array}{l}\text { Initially: } \\
\text { - South African } \\
\text { National } \\
\text { Defence } \\
\text { Force } \\
\text { - Members of } \\
\text { Parliament } \\
\text { Allegations also } \\
\text { involve: } \\
\text { - NPA } \\
\text { - SSA }\end{array}$ \\
\hline $\begin{array}{l}\text { Nkandla } \\
\text { Security } \\
\text { Upgrades }\end{array}$ & $\begin{array}{l}\text { Investigation } \\
\text { started in } \\
\text { November } 2012 . \\
\text { Report on } \\
\text { investigation } \\
\text { was released in } \\
\text { March } 2014 .\end{array}$ & $\begin{array}{l}\text { Report on security upgrades to President } \\
\text { Zuma's homestead in Nkandla. The investigation } \\
\text { found that the President unduly benefited from } \\
\text { the upgrades and as part of remedial actions } \\
\text { the President was required to pay back a portion } \\
\text { of the costs of the upgrades. Zuma instructed } \\
\text { that SAPS undertake their own investigation, } \\
\text { which sought to rationalise the expenses (fire- } \\
\text { pool report). Parliament accepted this alternative } \\
\text { report, but major court cases followed, } \\
\text { ultimately declaring that the Public Protector's } \\
\text { remedial actions are binding. President and } \\
\text { Parliament failed to uphold the Constitution. } \\
\text { President ordered to "pay back the money". }\end{array}$ & $\begin{array}{l}\text { - Public } \\
\text { Protector's } \\
\text { Secured } \\
\text { in Comfort } \\
\text { report, } \\
\text { followed by } \\
\text { litigation }\end{array}$ & 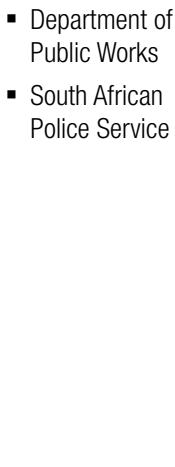 \\
\hline
\end{tabular}




\begin{tabular}{|c|c|c|c|c|}
\hline $\begin{array}{l}\text { Case Study } \\
\text { in State } \\
\text { Capture }\end{array}$ & Status & Summary Description & $\begin{array}{l}\text { Investigation } \\
\text { Body / } \\
\text { Source of } \\
\text { Evidence }\end{array}$ & $\begin{array}{l}\text { Government } \\
\text { Entity } \\
\text { Implicated }\end{array}$ \\
\hline \multicolumn{5}{|c|}{ Scandals Connected to Jacob Zuma, Guptas, Other Key Networks and ANC Politics } \\
\hline $\begin{array}{l}\text { Private } \\
\text { Aircraft } \\
\text { Landing at } \\
\text { Waterkloof } \\
\text { Airforce Base } \\
\text { and Gupta } \\
\text { Sun City } \\
\text { Wedding }\end{array}$ & May 2013. & $\begin{array}{l}\text { In 2013, justice, crime prevention, and } \\
\text { security cluster (JCPS) - a cabinet structure } \\
\text { composed of various ministries - undertook an } \\
\text { investigation into the Landing of a Commercial } \\
\text { aircraft at Air Force Base Waterkloof (report } \\
\text { titled the same). The investigation revealed that } \\
\text { the Guptas initially tried to organise a special } \\
\text { landing at OR Tambo International Airport, but } \\
\text { was turned down. They then approached the } \\
\text { Indian High Commission who re-designated the } \\
\text { wedding entourage as an official delegation to } \\
\text { secure a landing at the Waterkloof base. The } \\
\text { wedding held at Sun City was attended by a } \\
\text { number of high-profile ANC politicians and was } \\
\text { paid for in part by moneys looted from the Vrede } \\
\text { Dairy Farm project. }\end{array}$ & $\begin{array}{l}\text { - Report by } \\
\text { JPCS } \\
\text { - Zondo } \\
\text { Commission }\end{array}$ & $\begin{array}{l}\text { - Department of } \\
\text { International } \\
\text { Relations and } \\
\text { Cooperation } \\
\text { (DIRCO) } \\
\text { - Department of } \\
\text { Defence } \\
\text { - Department of } \\
\text { Transport }\end{array}$ \\
\hline $\begin{array}{l}\text { Free State } \\
\text { Provincial } \\
\text { Capture, } \\
\text { includes } \\
\text { Vrede Dairy } \\
\text { Farm and } \\
\text { Asbestos } \\
\text { Contracts }\end{array}$ & Ongoing. & $\begin{array}{l}\text { The Vrede Dairy Farm project was initiated } \\
\text { by the Free State Provincial Government as a } \\
\text { development project, however, in partnering with } \\
\text { a Gupta-linked company Estina, government } \\
\text { funds were looted. In 2018, the Public } \\
\text { Protector released a report on their } 2018 \\
\text { investigation, but it was taken on review and } \\
\text { set aside by the courts. The second part of the } \\
\text { investigation is yet to be finalised. The NPA } \\
\text { laid criminal charges against Gupta associates } \\
\text { and implicated government officials. Court } \\
\text { proceedings are ongoing. } \\
\text { Significant testimony and evidence have been } \\
\text { presented at the Zondo Commission regarding } \\
\text { the Vrede Farm case, as well as the asbestos } \\
\text { inspection project (criminal proceedings are also } \\
\text { underway). Both projects implicate high-profile } \\
\text { politicians and senior officials manipulating } \\
\text { government process. }\end{array}$ & $\begin{array}{l}\text { - } \text { Public } \\
\text { Protector } \\
\text { reports } \\
\text { - Zondo } \\
\text { Commission } \\
\text { - Various } \\
\text { court cases }\end{array}$ & $\begin{array}{l}\text { - Free State } \\
\text { Provincial } \\
\text { Government }\end{array}$ \\
\hline $\begin{array}{l}\text { Irregular } \\
\text { removal of } \\
\text { National } \\
\text { Director } \\
\text { of Public } \\
\text { Prosecutions } \\
\text { (NDPP), } \\
\text { Mxolisi } \\
\text { Nxasana }\end{array}$ & $\begin{array}{l}\text { Inquiry instituted } \\
\text { in February } 2015, \\
\text { but was cancelled } \\
\text { in May } 2015 . \\
\text { This triggers the } \\
\text { Constitutional Court } \\
\text { cases that followed. }\end{array}$ & $\begin{array}{l}\text { Inquiry into the fitness of Mxolisi Nxasana to } \\
\text { hold office as NDPP. The Inquiry was cancelled } \\
\text { after Zuma "agreed to let Nxasana resign". He } \\
\text { was paid R17m - the balance of his ten-year } \\
\text { contract. Court cases followed detailing the } \\
\text { abuse of the presidency powers by Zuma. } \\
\text { Ultimately, Nxasana was ordered to repay } \\
\text { R17m and Zuma's appointed replacement, } \\
\text { Shawn Abrahams, was ordered to vacate office. } \\
\text { Constitutional Court found Zuma's actions to } \\
\text { be an abuse of power and in breach of his } \\
\text { constitutional obligations. }\end{array}$ & $\begin{array}{l}\text { - Cassim } \\
\text { Inquiry into } \\
\text { fitness of } \\
\text { Mxolisi } \\
\text { Nxasana to } \\
\text { hold office } \\
\text { of NDPP } \\
\text { initiated } \\
\text { by Zuma, } \\
\text { followed by } \\
\text { litigation }\end{array}$ & $\begin{array}{l}\text { - National } \\
\text { Prosecution } \\
\text { Authority }\end{array}$ \\
\hline $\begin{array}{l}\text { Political } \\
\text { killings in } \\
\text { KZN }\end{array}$ & $\begin{array}{l}\text { Established in } \\
\text { October } 2016 . \text { The } \\
\text { report was released } \\
\text { in May } 2018 .\end{array}$ & $\begin{array}{l}\text { On } 28 \text { October 2016, the Premier of the } \\
\text { Province of KwaZulu-Natal established a } \\
\text { Commission of Enquiry into the Underlying } \\
\text { Causes of the Murder of Politicians in KwaZulu- } \\
\text { Natal (KZN). }\end{array}$ & $\begin{array}{l}\text { - Moerane } \\
\text { Commission } \\
\text { of Enquiry }\end{array}$ & $\begin{array}{l}\text { - KZN Provincial } \\
\text { Government } \\
\text { - KZN Local } \\
\text { Governments }\end{array}$ \\
\hline
\end{tabular}




\begin{tabular}{|c|c|c|c|c|}
\hline $\begin{array}{l}\text { Case Study } \\
\text { in State } \\
\text { Capture }\end{array}$ & Status & Summary Description & $\begin{array}{l}\text { Investigation } \\
\text { Body / } \\
\text { Source of } \\
\text { Evidence } \\
\end{array}$ & $\begin{array}{l}\text { Government } \\
\text { Entity } \\
\text { Implicated }\end{array}$ \\
\hline \multicolumn{5}{|c|}{ Scandals Connected to Jacob Zuma, Guptas, Other Key Networks and ANC Politics } \\
\hline \multicolumn{5}{|c|}{ State Capture of State-Owned Enterprises and Government Departments } \\
\hline $\begin{array}{l}\text { Interference } \\
\text { in operations } \\
\text { at the SABC }\end{array}$ & $\begin{array}{l}\text { The Ad Hoc } \\
\text { Committee was } \\
\text { established in } \\
\text { November } 2016 \\
\text { and final report } \\
\text { was tabled on } \\
24 \text { February } 2017 .\end{array}$ & $\begin{array}{l}\text { Parliamentary Ad Hoc Committee on the } \\
\text { SABC Board Inquiry into mismanagement and } \\
\text { interference in SABC operations. Findings } \\
\text { include evidence of Minister Faith Muthambi's } \\
\text { interference in the organisation and editorial } \\
\text { interference, in the firing of SABC } 8 \text { who } \\
\text { protested censorship of the national broadcaster } \\
\text { (on instruction from COO Hlaudi Motsoeneng). It } \\
\text { should be noted that the inquiry was preceded } \\
\text { by an investigation by the Public Protector. } \\
\text { Details are contained in the } 2014 \text { report titled } \\
\text { When Governance and Ethics Fail. }\end{array}$ & $\begin{array}{l}\text { - Parliamen- } \\
\text { tary Inquiry } \\
\text { - Preceded by } \\
\text { an investi- } \\
\text { gation by } \\
\text { the Public } \\
\text { Protector }\end{array}$ & $\begin{array}{l}\text { - SABC } \\
\text { (Department } \\
\text { of Communi- } \\
\text { cation) }\end{array}$ \\
\hline \multirow[t]{2}{*}{$\begin{array}{l}\text { Passenger } \\
\text { Rail Agency } \\
\text { of South } \\
\text { Africa } \\
\text { (PRASA) }\end{array}$} & $\begin{array}{l}\text { Complaints were } \\
\text { lodged in } 2012 \\
\text { and the report } \\
\text { was released in } \\
\text { August } 2015 .\end{array}$ & $\begin{array}{l}\text { Several cases of "mismanagement and } \\
\text { irregularities" regarding various contracts. } \\
\text { Lucky Montana was CEO at the time. One of } \\
\text { the remedial actions stipulated that National } \\
\text { Treasury was to investigate all PRASA contracts } \\
\text { from } 2012 \text { onwards with a value of R10 million } \\
\text { or more. National Treasury implemented the } \\
\text { remedial action which resulted in several } \\
\text { investigations, the details of which were leaked } \\
\text { to the public. }\end{array}$ & $\begin{array}{l}\text { - Public } \\
\text { Protector's } \\
\text { Derailed } \\
\text { report on } \\
\text { PRASA } \\
\text { - Numerous } \\
\text { investiga- } \\
\text { tions }\end{array}$ & $\begin{array}{l}\text { - PRASA } \\
\text { - Department of } \\
\text { Transport }\end{array}$ \\
\hline & $\begin{array}{l}\text { In June } 2017, \\
\text { Parliament directed } \\
4 \text { committees to } \\
\text { investigate state } \\
\text { capture. Committee } \\
\text { hearings were not } \\
\text { completed. }\end{array}$ & $\begin{array}{l}\text { In terms of the parliamentary directive, the } \\
\text { Portfolio Committee on Transport was requested } \\
\text { to establish an Inquiry into State Capture at } \\
\text { PRASA. However, the Portfolio Committee noted } \\
\text { that PRASA was not mentioned in the Public } \\
\text { Protector's State of Capture report and decided } \\
\text { they would focus on the various investigation } \\
\text { reports produced for National Treasury (as } \\
\text { recommended in Derailed report). }\end{array}$ & $\begin{array}{l}\text { - Portfolio } \\
\text { Committee } \\
\text { on Transport }\end{array}$ & $\begin{array}{l}\text { - PRASA } \\
\text { - Department of } \\
\text { Transport }\end{array}$ \\
\hline $\begin{array}{l}\text { Eskom } \\
\text { Inquiry into } \\
\text { State Capture }\end{array}$ & $\begin{array}{l}\text { In June } 2017 \text {, } \\
\text { Parliament directed } \\
4 \text { committees } \\
\text { to investigate } \\
\text { state capture. } \\
\text { Public Enterprises } \\
\text { Committee } \\
\text { report on Eskom } \\
\text { was released in } \\
\text { November } 2018 .\end{array}$ & $\begin{array}{l}\text { Extensive hearings were held by the Committee } \\
\text { detailing much of the evidence presented in } \\
\text { the Public Protector's report. The Committee } \\
\text { presented recommendations and compiled } \\
\text { a final report detailing their findings. These } \\
\text { included findings that Ministers Lynne Brown } \\
\text { and Malusi Gigaba were negligent and had to } \\
\text { be held accountable. Also recommended that } \\
\text { criminal investigations be undertaken against } \\
\text { the relevant Eskom executives. }\end{array}$ & $\begin{array}{l}\text { - Parliamen- } \\
\text { tary Inquiry }\end{array}$ & $\begin{array}{l}\text { - Eskom } \\
\text { - Department } \\
\text { of Public } \\
\text { Enterprises }\end{array}$ \\
\hline $\begin{array}{l}\text { Nugent } \\
\text { Commission } \\
\text { - SARS } \\
\text { Inquiry }\end{array}$ & $\begin{array}{l}\text { The Inquiry was } \\
\text { constituted on } \\
24 \text { May } 2018 \text { and } \\
\text { the final report } \\
\text { was released in } \\
\text { December } 2018 .\end{array}$ & $\begin{array}{l}\text { Commission of Inquiry into tax administration } \\
\text { and governance by South African Revenue } \\
\text { Service (SARS). Tom Moyane was fired based on } \\
\text { the interim report released in September } 2018 . \\
\text { The inquiry found that Moyane, with the help of } \\
\text { consultancy company Bain, had implemented } \\
\text { restructuring of the organisation, resulting in } \\
\text { gross mismanagement and erosion of SARS. } \\
\text { Moyane motivated the restructuring based on } \\
\text { the "rogue unit" narrative that has been the } \\
\text { subject of several other debunked investigations } \\
\text { and the subject of much litigation. }\end{array}$ & $\begin{array}{l}\text { - Judicial } \\
\text { Commission } \\
\text { of Inquiry } \\
\text { - Court cases } \\
\text { around the } \\
\text { "rogue unit" } \\
\text { narrative }\end{array}$ & $\begin{array}{l}\text { - SARS } \\
\text { (National } \\
\text { Treasury) }\end{array}$ \\
\hline
\end{tabular}




\begin{tabular}{|c|c|c|c|c|}
\hline $\begin{array}{l}\text { Case Study } \\
\text { in State } \\
\text { Capture }\end{array}$ & Status & Summary Description & $\begin{array}{l}\text { Investigation } \\
\text { Body / } \\
\text { Source of } \\
\text { Evidence }\end{array}$ & $\begin{array}{l}\text { Government } \\
\text { Entity } \\
\text { Implicated }\end{array}$ \\
\hline \multicolumn{5}{|c|}{ Scandals Connected to Jacob Zuma, Guptas, Other Key Networks and ANC Politics } \\
\hline \multicolumn{5}{|c|}{ State Capture of State-Owned Enterprises and Government Departments } \\
\hline $\begin{array}{l}\text { Commission } \\
\text { of Inquiry } \\
\text { into Public } \\
\text { Investment } \\
\text { Corporation } \\
\text { (PIC) }\end{array}$ & $\begin{array}{l}\text { In October } 2018 \text {, } \\
\text { the Commission } \\
\text { was constituted, } \\
\text { and the final report } \\
\text { was released in } \\
\text { March } 2020 .\end{array}$ & $\begin{array}{l}\text { Commission of Inquiry into allegations of } \\
\text { impropriety regarding Public Investment } \\
\text { Corporation (PIC). There were extensive hearings } \\
\text { on various 'dodgy' deals the PIC entered } \\
\text { into and details of political and executive } \\
\text { interference in the operations and decision- } \\
\text { making processes of the investment agency. }\end{array}$ & $\begin{array}{l}\text { - Judicial } \\
\text { Commission } \\
\text { of Inquiry }\end{array}$ & $\begin{array}{l}\text { - PIC (National } \\
\text { Treasury) }\end{array}$ \\
\hline $\begin{array}{l}\text { South African } \\
\text { Social } \\
\text { Security } \\
\text { Agency } \\
\text { (SASSA) }\end{array}$ & $\begin{array}{l}\text { Various } \\
\text { Constitutional Court } \\
\text { cases from } 2011 \\
\text { to } 2018 \text { resulted } \\
\text { in removal of CPS } \\
\text { as service provider } \\
\text { to SASSA. }\end{array}$ & $\begin{array}{l}\text { In 2014, South African Social Security Agency's } \\
\text { (SASSA) } 2012 \text { contract with CPS was found } \\
\text { to be irregular and invalid, however, due to the } \\
\text { importance of ensuring beneficiaries received } \\
\text { grants, CPS continued to be the service } \\
\text { providers until } 2018 \text {. Following a March } 2017 \\
\text { ruling, the Constitutional Court instituted a } \\
\text { Section } 38 \text { Inquiry into Minister Bathabile } \\
\text { Dlamini's personal liability for the narrowly } \\
\text { averted grant payment crisis. }\end{array}$ & $\begin{array}{l}\text { Primary } \\
\text { sources: } \\
\text { - AllPay court } \\
\text { case } \\
\text { - Black Sash } \\
\text { court case }\end{array}$ & - SASSA \\
\hline $\begin{array}{l}\text { South African } \\
\text { Airways (SAA) } \\
\text { and SAA } \\
\text { Technical }\end{array}$ & $\begin{array}{l}\text { Court case } \\
\text { to have Dudu } \\
\text { Myeni declared a } \\
\text { delinquent director } \\
\text { was launched } \\
\text { in } 2017 .\end{array}$ & $\begin{array}{l}\text { Court case was launched in } 2017 \text { by Outa and } \\
\text { the SAA Pilots' Association (SAAPA) to declare } \\
\text { Myeni a delinquent director in terms of the } \\
\text { Companies Act, based on her actions while she } \\
\text { was chairperson of the SAA Board. In 2020, the } \\
\text { High Court declared Myeni a delinquent director } \\
\text { for life. A significant amount of new evidence } \\
\text { also emerged through the Zondo Commission, } \\
\text { outlining how the operations at SAA were } \\
\text { undermined and how Myeni and others abused } \\
\text { their positions of authority. }\end{array}$ & $\begin{array}{l}\text { - Court } \\
\text { papers } \\
\text { - Zondo } \\
\text { Commission }\end{array}$ & $\begin{array}{l}\text { - SAA } \\
\text { - SAA Technical }\end{array}$ \\
\hline $\begin{array}{l}\text { Gupta Family } \\
\text { Naturalisation }\end{array}$ & $\begin{array}{l}\text { In June } 2017, \\
\text { Parliament directed } \\
4 \text { committees to } \\
\text { investigate state } \\
\text { capture. Final } \\
\text { report was tabled } \\
14 \text { March } 2019 .\end{array}$ & $\begin{array}{l}\text { Portfolio Committee on Home Affairs Inquiry into } \\
\text { the Gupta Family Naturalisation was established } \\
\text { in terms of the Parliamentary directive. Hearings } \\
\text { formally started on } 12 \text { September 2018. Final } \\
\text { report was tabled on } 14 \text { March 2019. Questions } \\
\text { were raised around contracts with Visa } \\
\text { Facilitation Services. This matter is ongoing as } \\
\text { of December } 2020 \text {. }\end{array}$ & $\begin{array}{l}\text { - Portfolio } \\
\text { Committee } \\
\text { on Home } \\
\text { Affairs }\end{array}$ & $\begin{array}{l}\text { - Department of } \\
\text { Home Affairs }\end{array}$ \\
\hline $\begin{array}{l}\text { Inquiry into } \\
\text { State Capture } \\
\text { related to } \\
\text { Gupta-owned } \\
\text { mines }\end{array}$ & $\begin{array}{l}\text { In June } 2017, \\
\text { Parliament directed } \\
4 \text { committees } \\
\text { to investigate } \\
\text { state capture. }\end{array}$ & $\begin{array}{l}\text { Though the Committee drafted a term of } \\
\text { reference for the Inquiry, the activities of holding } \\
\text { hearings and consolidating the evidence never } \\
\text { materialised beyond questions being put to then } \\
\text { Minister Zwane. }\end{array}$ & $\begin{array}{l}\text { - Portfolio } \\
\text { Committee } \\
\text { on Mineral } \\
\text { Resources }\end{array}$ & $\begin{array}{l}\text { - Department } \\
\text { of Mineral } \\
\text { Resources }\end{array}$ \\
\hline
\end{tabular}




\begin{tabular}{|c|c|c|c|c|}
\hline $\begin{array}{l}\text { Case Study } \\
\text { in State } \\
\text { Capture }\end{array}$ & Status & Summary Description & $\begin{array}{l}\text { Investigation } \\
\text { Body / } \\
\text { Source of } \\
\text { Evidence }\end{array}$ & $\begin{array}{l}\text { Government } \\
\text { Entity } \\
\text { Implicated }\end{array}$ \\
\hline \multicolumn{5}{|c|}{ Scandals Connected to Jacob Zuma, Guptas, Other Key Networks and ANC Politics } \\
\hline \multicolumn{5}{|c|}{ State Capture of State-Owned Enterprises and Government Departments } \\
\hline \multirow{3}{*}{$\begin{array}{l}\text { Various } \\
\text { investigations } \\
\text { relating to } \\
\text { State Capture } \\
\text { at Eskom }\end{array}$} & 2015 & $\begin{array}{l}\text { In 2015, Dentons produced an interim report } \\
\text { on their investigations into Status of Business } \\
\text { and Challenges at Eskom. Their investigation } \\
\text { was halted. }\end{array}$ & - Eskom & - Eskom \\
\hline & \multirow[t]{2}{*}{2017} & $\begin{array}{l}\text { In 2017, PricewaterhouseCoopers (PwC) was } \\
\text { appointed by National Treasury to investigate } \\
\text { Eskom's Coal Procurement Processes. Damning } \\
\text { findings were made in relation to Gupta-owned } \\
\text { Tegeta mine contracts and poor coal quality. }\end{array}$ & - Eskom & - Eskom \\
\hline & & $\begin{array}{l}\text { G9 was contracted by Eskom to investigate } \\
\text { the Trillian/McKinsey contracts. Interim report } \\
\text { presented to Board of Eskom in August } 2017 . \\
\text { The investigation remained incomplete, and } \\
\text { no report is available in the public domain. } \\
\text { Evidence from the investigation was presented } \\
\text { in the Parliamentary Inquiry into Eskom } \\
\text { State Capture. }\end{array}$ & $\begin{array}{l}\text { - National } \\
\text { Treasury }\end{array}$ & - Eskom \\
\hline $\begin{array}{l}\text { National } \\
\text { Treasury } \\
\text { Fundudzi } \\
\text { reports, } \\
\text { related to } \\
\text { Eskom and } \\
\text { Transnet (x3) }\end{array}$ & $\begin{array}{l}\text { Final reports } \\
\text { compiled in } \\
\text { November } 2018 \\
\text { and released to } \\
\text { the public shortly } \\
\text { thereafter. }\end{array}$ & $\begin{array}{l}\text { Investigations requested by National Treasury } \\
\text { of alleged corruption at Transnet and Eskom. } \\
\text { The three reports focused on Eskom (general), } \\
\text { the contracts related to Trillian/McKinsey and } \\
\text { Transnet Locomotives. }\end{array}$ & $\begin{array}{l}\text { - National } \\
\text { Treasury } \\
\text { Fundudzi }\end{array}$ & $\begin{array}{l}\text { - Eskom } \\
\text { - Transnet }\end{array}$ \\
\hline \multirow[t]{2}{*}{$\begin{array}{l}\text { Transnet } \\
\text { Locomotive } \\
\text { Contracts }\end{array}$} & \multirow[t]{2}{*}{$\begin{array}{l}\text { Investigations } \\
\text { commenced in } \\
\text { December } 2017 \\
\text { and reports on } \\
\text { findings submitted } \\
\text { during } 2018 .\end{array}$} & $\begin{array}{l}\text { Werksmans Attorneys was appointed in } \\
\text { December } 2017 \text { to undertake an investigation } \\
\text { into the } 1064 \text { Transnet Locomotives } \\
\text { procurement process, however, the investigation } \\
\text { was halted. No report in the public domain. }\end{array}$ & - Werksmans & - Transnet \\
\hline & & $\begin{array}{l}\text { Mncedisi Ndlovu \& Sedumedi (MNS) Attorneys } \\
\text { was then appointed to investigate } 1064 \\
\text { locomotives procurement process. The report } \\
\text { is not in the public domain, but media indicates } \\
\text { that recommendations mirror the Werksmans' } \\
\text { findings and recommends that Molefe face } \\
\text { criminal charges. }\end{array}$ & $\begin{array}{l}\text { - Mncedisi } \\
\text { Ndlovu \& } \\
\text { Sedumedi }\end{array}$ & - Transnet \\
\hline $\begin{array}{l}\text { Inquiry into } \\
\text { State Capture } \\
\text { at Transnet } \\
\text { and Denel }\end{array}$ & $\begin{array}{l}\text { In June } 2017, \\
\text { Parliament directed } \\
4 \text { committees to } \\
\text { investigate state } \\
\text { capture. Committee } \\
\text { hearings were not } \\
\text { completed. }\end{array}$ & $\begin{array}{l}\text { A detailed information booklet was prepared } \\
\text { in relation to Transnet, however, hearings were } \\
\text { not held before the end of term of Parliament. } \\
\text { Following National elections in 2019, it } \\
\text { was decided that outstanding Inquiries into } \\
\text { state capture be postponed indefinitely until } \\
\text { conclusion of the Zondo Commission. }\end{array}$ & $\begin{array}{l}\text { - Portfolio } \\
\text { Committee } \\
\text { on Public } \\
\text { Enterprises }\end{array}$ & $\begin{array}{l}\text { - Transnet } \\
\text { - Denel }\end{array}$ \\
\hline
\end{tabular}




\begin{tabular}{|c|c|c|c|c|}
\hline $\begin{array}{l}\text { Case Study } \\
\text { in State } \\
\text { Capture }\end{array}$ & Status & Summary Description & $\begin{array}{l}\text { Investigation } \\
\text { Body / } \\
\text { Source of } \\
\text { Evidence }\end{array}$ & $\begin{array}{l}\text { Government } \\
\text { Entity } \\
\text { Implicated }\end{array}$ \\
\hline \multicolumn{5}{|c|}{ Scandals Connected to Jacob Zuma, Guptas, Other Key Networks and ANC Politics } \\
\hline \multicolumn{5}{|c|}{ Law Enforcement and the Security Cluster } \\
\hline $\begin{array}{l}\text { Enquiry into } \\
\text { Jiba and } \\
\text { Mrwebi's } \\
\text { fitness to } \\
\text { hold office } \\
\text { at NPA }\end{array}$ & $\begin{array}{l}\text { Established in } \\
\text { November } 2018 . \\
\text { Report was issued } \\
\text { in April } 2019 .\end{array}$ & $\begin{array}{l}\text { Presidential Enquiry into the fitness to hold } \\
\text { office of suspended NPA senior advocates } \\
\text { Nomgcobo Jiba and Lawrence Mrwebi. NPA's } \\
\text { deputy head Jiba, and Mrwebi, the head of } \\
\text { the Specialised Commercial Crimes Unit, were } \\
\text { suspended in October } 2018 \text { by President Cyril } \\
\text { Ramaphosa. The Inquiry was headed by retired } \\
\text { Constitutional Court Justice Yvonne Mokgoro. } \\
\text { Jiba and Mrwebi were accused of improper } \\
\text { conduct in their handling of cases involving } \\
\text { former crime intelligence head Richard Mdluli, } \\
\text { as well as former KwaZulu-Natal Hawks boss } \\
\text { Johan Booysen. }\end{array}$ & $\begin{array}{c}\text { - Mokgoro } \\
\text { Enquiry }\end{array}$ & $\begin{array}{l}\text { - } \text { National } \\
\text { Prosecuting } \\
\text { Authority }\end{array}$ \\
\hline $\begin{array}{l}\text { High-Level } \\
\text { Review Panel } \\
\text { on the State } \\
\text { Security } \\
\text { Agency (SSA) }\end{array}$ & $\begin{array}{l}\text { Established in June } \\
2018 \text { and final } \\
\text { report was sent to } \\
\text { the President in } \\
\text { December } 2018 .\end{array}$ & $\begin{array}{l}\text { The High-Level Review Panel into the SSA } \\
\text { was established by President Ramaphosa in } \\
\text { June 2018. The key finding was a serious } \\
\text { politicisation and factionalisation of the } \\
\text { intelligence community over the past decade } \\
\text { or more. This resulted in "an almost complete } \\
\text { disregard for the Constitution, policy, legislation } \\
\text { and other prescripts, and [turned] our civilian } \\
\text { intelligence community into a private resource } \\
\text { to serve the political and personal interests of } \\
\text { particular individuals" (High-Level Review Panel } \\
\text { on the SSA, 2018, p.ii). }\end{array}$ & $\begin{array}{l}\text { - Review } \\
\text { Panel } \\
\text { established } \\
\text { by President } \\
\text { Ramaphosa }\end{array}$ & - SSA \\
\hline $\begin{array}{l}\text { Various court } \\
\text { cases against } \\
\text { persons } \\
\text { within law } \\
\text { enforcement }\end{array}$ & Ongoing. & $\begin{array}{l}\text { Though testimony and evidence have been } \\
\text { presented at the Zondo Commission, it is } \\
\text { understood that no definitive findings will be } \\
\text { made regarding the capture of law enforcement } \\
\text { under the Zuma administration. Since } 2012 \\
\text { onwards, there were several court cases } \\
\text { that were pursued against individuals in law } \\
\text { enforcement, all of which have been either } \\
\text { dismissed or withdrawn. Most noteworthy are } \\
\text { the cases involved, amongst others: Anwa } \\
\text { Dramat and Shadrack Sibiya of the Hawks } \\
\text { (and Robert McBride from Independent Police } \\
\text { Investigative Directorate [IPID]) for allegations } \\
\text { related to the "Zimbabwean rendition" matter; } \\
\text { Johan Booysen for alleged racketeering as part } \\
\text { of "Cato Manor hit squad"; and the various } \\
\text { senior officials accused of being part of the } \\
\text { "rogue" intelligence unit at SARS. Other court } \\
\text { cases that have provided significant evidence } \\
\text { indicating the capture of law enforcement relate } \\
\text { to the irregular appointed allies of the Shadow } \\
\text { State capture network or the irrational removal } \\
\text { of potential opponents holding senior positions } \\
\text { in law enforcement. Example is the irregular } \\
\text { removal of Mxolisi Nxasana as National Director } \\
\text { of Public Prosecutions (NDPP). }\end{array}$ & $\begin{array}{l}\text { - Various } \\
\text { court cases, } \\
\text { proceedings } \\
\text { in Parlia- } \\
\text { ment } \\
\text { - Zondo } \\
\text { Commission }\end{array}$ & $\begin{array}{l}\text { - NPA } \\
\text { - SAPS } \\
\text { - Hawks } \\
\text { - IPID }\end{array}$ \\
\hline
\end{tabular}




\begin{tabular}{|c|c|c|c|c|}
\hline $\begin{array}{l}\text { Case Study } \\
\text { in State } \\
\text { Capture }\end{array}$ & Status & Summary Description & $\begin{array}{l}\text { Investigation } \\
\text { Body / } \\
\text { Source of } \\
\text { Evidence }\end{array}$ & $\begin{array}{l}\text { Government } \\
\text { Entity } \\
\text { Implicated }\end{array}$ \\
\hline \multicolumn{5}{|c|}{ Scandals Connected to Jacob Zuma, Guptas, Other Key Networks and ANC Politics } \\
\hline \multicolumn{5}{|c|}{ Investigations concerning Private Sector } \\
\hline $\begin{array}{l}\text { Budlender } \\
\text { report on } \\
\text { Trillian }\end{array}$ & $\begin{array}{l}\text { Released in } \\
\text { June } 2017 .\end{array}$ & $\begin{array}{l}\text { Trillian Holdings Board appointed Geoff } \\
\text { Budlender SC to undertake investigations into } \\
\text { State Capture allegations at Trillian Capital. } \\
\text { Detailed accounts from whistle-blowers } \\
\text { highlighted how information was withheld by } \\
\text { senior management at Trillian. }\end{array}$ & - Trillion & - Eskom \\
\hline $\begin{array}{l}\text { Collapse of } \\
\text { VBS Mutual } \\
\text { Bank }\end{array}$ & $\begin{array}{l}\text { Investigation } \\
\text { launched in } \\
\text { April } 2018 \text { and } \\
\text { the report was } \\
\text { released in } \\
\text { October } 2018 .\end{array}$ & $\begin{array}{l}\text { Minister of Finance placed VBS under } \\
\text { curatorship with effect from } 11 \text { March 2018. In } \\
\text { April 2018, the Deputy Governor of the South } \\
\text { African Reserve Bank instituted an investigation } \\
\text { into VBS. The outcomes of the investigation } \\
\text { showed blatant fraud and corruption by senior } \\
\text { executives/Board and how they extracted } \\
\text { money from the bank. Municipal funds were } \\
\text { illegally deposited with VBS (senior ANC and } \\
\text { EFF politicians have been implicated). }\end{array}$ & $\begin{array}{l}\text { - SARB } \\
\text { investiga- } \\
\text { tion report } \\
\text { VBS Mutual } \\
\text { Bank - The } \\
\text { Great Bank } \\
\text { Heist }\end{array}$ & $\begin{array}{l}\text { - Several } \\
\text { Provincial and } \\
\text { Municipal } \\
\text { Officials } \\
\text { (Limpopo } \\
\text { Government) } \\
\text { - SOEs } \\
\text { (particularly } \\
\text { PRASA) }\end{array}$ \\
\hline $\begin{array}{l}\text { SA Institute } \\
\text { of Chartered } \\
\text { Accountants' } \\
\text { (SAICA) } \\
\text { investigation } \\
\text { into KPMG }\end{array}$ & $\begin{array}{l}\text { Final report was } \\
\text { handed to SAICA in } \\
\text { December } 2018 .\end{array}$ & $\begin{array}{l}\text { SA Institute of Chartered Accountants (SAICA) } \\
\text { established an Inquiry to investigate state } \\
\text { capture related allegations of misconduct of its } \\
\text { members who worked for KPMG. The Inquiry } \\
\text { chaired by advocate Dumisa Ntsebeza held } \\
\text { public hearings and handed its final report to } \\
\text { SAICA in December 2018. Indications are that } \\
\text { the final report will not be made public until all } \\
\text { investigations and disciplinary hearings have } \\
\text { been finalised. }\end{array}$ & - SAICA & - Guptas \\
\hline Bell Pottinger & $\begin{array}{l}2017 \text { investigation } \\
\text { by PRCA. }\end{array}$ & $\begin{array}{l}\text { In 2016, the Guptas appointed British PR } \\
\text { company, Bell Pottinger, who developed and } \\
\text { promoted a campaign that underpinned the RET } \\
\text { and WMC narratives. In 2017, there was an } \\
\text { independent law firm review by Herbert Smith } \\
\text { Freehills resulting in Bell Pottinger's expulsion } \\
\text { from the Public Relations and Communications } \\
\text { Association (PRCA). }\end{array}$ & $\begin{array}{l}\text { - PRCA } \\
\text { - GuptaLeaks } \\
\text { - Ongoing } \\
\text { research } \\
\text { on disinfor- } \\
\text { mation }\end{array}$ & - Guptas \\
\hline
\end{tabular}

